\title{
Large-scale evaluation of the effects of adaptation to climate change by shifting transplanting date on rice production and quality in Japan
}

\author{
Yasushi Ishigooka ${ }^{\mathrm{a}, \dagger}$, Shin FukUI ${ }^{\mathrm{b}}$, Toshihiro Hasegawa ${ }^{\mathrm{c}}$, \\ Tsuneo KuwagATA ${ }^{a}$, Motoki Nishimori ${ }^{\mathrm{a}}$ and Motohiko Kondo ${ }^{\mathrm{d}}$ \\ a Institute for Agro-Environmental Sciences, National Agriculture and Food Research Organization, \\ 3-1-3 Kannondai, Tsukuba, Ibaraki 305-8604, Japan. \\ ${ }^{\mathrm{b}}$ Faculty of Human Sciences, Waseda University, 2-579-15 Mikajima, Tokorozawa, Saitama 359-1192, Japan. \\ ${ }^{\mathrm{c}}$ Tohoku Agricultural Research Center, National Agriculture and Food Research Organization, \\ 4 Akahira, Shimo-kuriyagawa, Morioka, Iwate 020-0198, Japan. \\ ${ }^{\mathrm{d}}$ Department of Biosphere Resources Science, Graduate School of Bioagricultural Sciences, Nagoya University, \\ Furo-cho, Chikusa-ku, Nagoya 464-8601, Japan.
}

\begin{abstract}
We evaluated the effect of projected increasing temperatures due to climate change on the yield and quality of rice, as well as the effectiveness of shifting the transplanting date as an adaptation measure, throughout Japan. As an indicator of rice quality, we adopted the heat stress index HD_m26, which is related to the decreased percentage of first grade rice due to high temperature, calculated as the cumulative temperature within 20 days after the heading date. We used a process-based rice growth model to assess the effect. We implemented the model for the period 1981-2100, and shifted the transplanting dates at 7-day intervals from -70 to +70 days from the standard transplanting date. The estimated yield was categorized into three classes with different degrees of quality degradation risk according to values of HD_ $\mathrm{m} 26$. Relative to the current transplanting date, nationwide total production was estimated to increase slightly in most climate change scenarios, although the proportion of production with quality degradation risk may increase with the rise in temperature. It may be possible to avoid this increased risk while maintaining total production by selecting an optimum transplanting date in consideration of both yield and quality. However, a large decrease in yield was found in some areas, suggesting that the current rice producing regions in Japan would become separated into suitable and unsuitable areas as temperatures increase.
\end{abstract}

Key words: $\mathrm{CO}_{2}$ fertilization effect, Heat stress index, Process-based rice simulation model, Rice yield

\section{Introduction}

Crop growth is highly dependent on climate, and thus agriculture is considered to be one of the most vulnerable sectors to climate change. In Japan, the effects of climate change on the productivity of major crops have attracted much attention in the context of recent frequent extreme summer temperatures, especially after the 1990s (Ishigooka et al., 2011), as well as the series of reports from the Intergovernmental Panel on Climate Change (IPCC) on projected future climate change (e.g., IPCC, 2014). Recent warming trends have already significantly affected nearly all types of crops and livestock in Japan (Sugiura et al., 2012). In the agricultural sector, therefore, the effects of climate change are recognized as an actual phenomenon that has been already occurring, rather than as a predicted one that may occur in the future.

Rice is the most important cereal crop in Japan, and thus the impact of projected climate change on rice productivity at the regional or national scale has been evaluated in many studies (e.g.,

Received; December 15, 2016

Accepted; April 11, 2017

'Corresponding Author: isigo@affrc.go.jp

DOI: 10.2480 /agrmet.D-16-00024
Horie et al., 1995b; Seino, 1997; Yonemura et al., 1998; Hayashi et al., 2001; Iizumi et al., 2006, 2011; Yokozawa et al., 2009). Most studies predicted the potential impact of climate change on rice productivity by implementing crop models that calculate crop development and yield by using the projected climate change scenarios derived from general circulation models (GCMs) as inputs. According to most of these studies, under the predicted warming conditions in Japan, rice yield is likely to increase in northern and northeastern Japan owing to a decrease in the frequency of cold damage, but is likely to decrease in other regions owing to the negative impacts of high temperature, such as a shortened growing period and increased spikelet sterility. However, there were various uncertainties in the methods used in their estimations.

In addition to yield, rice quality is an important factor in evaluating the impact of climate change on rice productivity. One major cause of the recent apparent decline in rice quality is the increase of white immature kernels due to high temperature, which tends to occur when the average temperature during the 20 days after the heading date is higher than 26 or $27^{\circ} \mathrm{C}$ (Morita et al., 2016). Several studies have attempted to develop a model for estimating the incidence of white immature kernels from meteorological factors (e.g., Nagahata et al., 2006; Nakagawa et al., 2008; Wakiyama et al., 2010; Masutomi et al., 2015; Yoshida et 
al., 2016). Most of these studies, however, focused on the field or regional scale or on a specific cultivar.

There are still limited researches which deal with the large-scale assessment of the impact of projected climate change on both yield and quality of rice. Okada et al. (2011a) examined these effects in the Kyushu region of western Japan using a climatically empirical rice quality model (Okada et al., 2011b) together with a process-based rice growth model (Iizumi et al., 2009; Yokozawa et al., 2009). They found that rice quality would deteriorate under any climatic scenarios used in their analyses and that the quality decrease can be reduced by shifting transplanting date later compare to the current while the yield may decrease. The effects of climate change on the quality and quantity of rice can vary across the different regions of Japan, but no such impact assessment across the entire country has been conducted.

In this study, we evaluated the impact of projected climate change on both the yield and quality of rice, as well as the effectiveness of shifting the transplanting date as an adaptation measure, targeting the whole of Japan. As the impact assessment model, we used the Hasegawa-Horie model (hereafter, "H/H model"), a process-based rice simulation model for estimating rice phenological development and yield developed by Hasegawa and Horie (1997) and recently modified by Fukui et al. (2015) and Yoshida et al. (2015). As for the quality of rice, unfortunately there is no appropriate model for quantitatively estimating the quality degradation associated with climatic variability at a national scale. Therefore, we adopted a heat stress index, which is related to rice quality degradation due to high temperature during the early reproductive stage; measured in heat degree-days, the index reflects the deviation in daily average air temperature from a base of $26^{\circ} \mathrm{C}$ during the 20 days after the heading date of rice (Nagahata et al., 2006; Ishigooka et al., 2011). Using the yield and the heat stress index as indicators, we explored the optimal transplanting date under the given climatic conditions and evaluated the effectiveness of shifting the transplanting date by comparing the results with and without this adaptation.

\section{Methodology and Data}

\subsection{Impact assessment model}

We used the $\mathrm{H} / \mathrm{H}$ model for predicting rice phenological change and formation of brown rice yield across Japan (Fig. 1). The model was implemented based on the "second-order mesh" which had been standardized by the Japanese Industrial Standards and defined as a resolution of $5^{\prime}$ latitude by $7.5^{\prime}$ longitude (approximately $10 \mathrm{~km} \times 10 \mathrm{~km}$ ). Japan as a whole is covered by about 4700 second-order mesh cells.

The H/H model has three major components: for phenological development, biomass production, and yield formation. The $\mathrm{H} / \mathrm{H}$ model is described in full by Hasegawa and Horie (1997), Fukui et al. (2015), and Yoshida et al. (2015). The all model parameters used in this study were the same as their studies. Here, we outline the calculation processes for each component and describe some characteristic features adopted in this model.

\subsubsection{Phenological development component}

The developmental stage is quantified by the developmental index (DVI), which is the increment in daily developmental rate (DVR) from seedling emergence to maturity. Many formulae for calculating DVR have been developed, as reviewed in Zhang and Tao (2013). In the original $\mathrm{H} / \mathrm{H}$ model (Hasegawa and Horie, 1997), DVR was given by the formula of Nakagawa and Horie (1995). However, that formula neglected the decrease of DVR at extremely high temperatures with the aim of simplifying the function (Horie and Nakagawa, 1990), detracting from the confidence in the simulation at high temperatures. Considering the objectives of this study, we adopted an alternative formula given by Nakagawa et al. (2005), in which the decrease in DVR at extremely high temperatures is represented by a $\beta$-function (Yin et al., 1997), as introduced in the latest version of the $\mathrm{H} / \mathrm{H}$ model (Yoshida et al., 2015). Fukui et al. (2015) estimated parameters of the DVR formula for 15 major rice cultivars, which accounted for $>80 \%$ of the entire rice cultivation area in Japan in 2005 (MAFF, 2006b), by using data collected during field experiments conducted across Japan and a stochastic genetic algorithm for optimization of parameters (Fukui et al., 2015). This methodology enabled to estimate parameters objectively without biases caused by the regional inhomogeneous distribution in the sample data. In their formula, DVR was calculated from daily mean temperature (average of daily maximum and minimum) and day length. In this study, the definition of DVI with each developmental stage was followed by Nakagwa and Horie (1995), in which $D V I=0$ at emergence, 1 at panicle initiation, 2 at heading, and 3 at maturity.

\subsubsection{Biomass production component}

In the $\mathrm{H} / \mathrm{H}$ model, estimates of the daily increases in biomass and leaf area are based on biophysical processes, along with the accumulation and allocation of nitrogen between plant and soil (Hasegawa and Horie, 1997).

The daily biomass increase is calculated as the difference between the products assimilated by photosynthesis and consumed by respiration (growth and maintenance). In the estimation of photosynthesis, the Ball-Berry stomatal conductance model (Collatz et al., 1991) is combined with the Farquhar-von

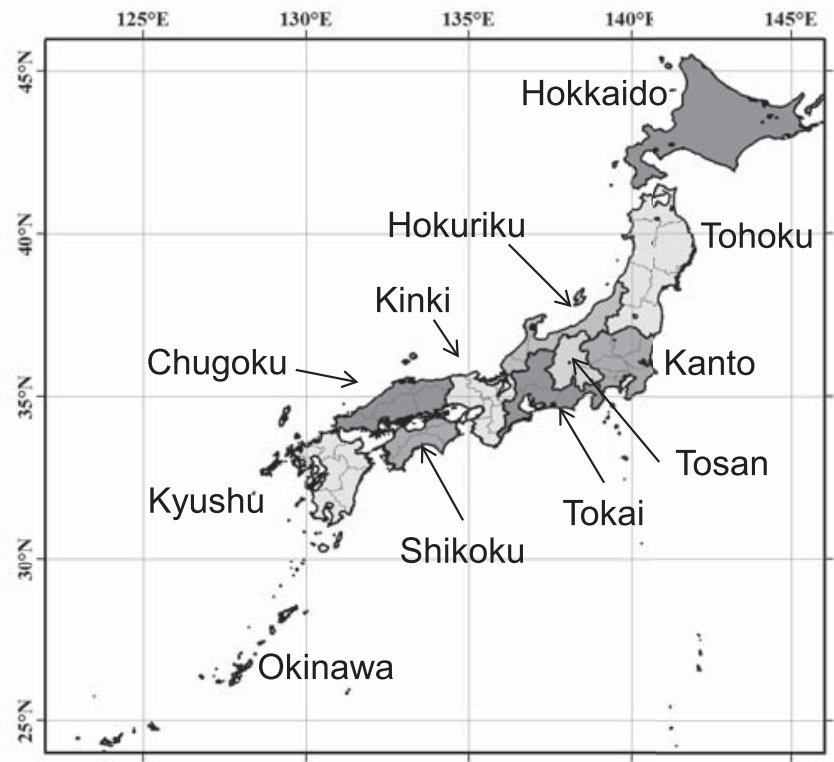

Fig. 1. The study area across Japan. Thick black lines are region boundaries, and thin gray lines show prefecture boundaries. 
Caemmerer-Berry photosynthesis model (Farquhar et al., 1980) to account for the effect of increasing atmospheric $\mathrm{CO}_{2}$ concentration on the enhancement of photosynthesis (for details, see Yoshida et $a l ., 2015)$. Through this process, the total biomass is calculated as the accumulation of daily biomass increase (dry matter).

\subsubsection{Yield formation component}

The yield (unhulled) is calculated by multiplying the biomass (dry weight production of the aboveground portion) and the harvest index. The harvest index is calculated by multiplying the potential harvest index (set to 0.5 , followed by Yoshida et al., 2015) and three adjustment factors: spikelet sterility caused by low temperature, that caused by high temperature, and delay of maturity; all of which are associated with the yield decrease (Horie et al., 1995a; Yoshida et al., 2015). Brown rice yield (hereafter called "rice yield") is estimated by multiplying the unhulled grain weight by 0.8 according to Yoshida (1981).

\subsubsection{Heat stress index for rice quality}

Many previous studies noted that the quality of rice grain declines when the daily mean temperature averaged over the 20 days after the heading date exceeds 26 to $27^{\circ} \mathrm{C}$ (e.g., Wakamatsu et al., 2007; Morita et al., 2016). The emergence of chalky grain, which causes quality degradation, can be described by a function, measured in heat degree-days, that reflects the deviation in daily average air temperature from a base of $26^{\circ} \mathrm{C}$ (Nagahata et al., 2006; Nakagawa et al., 2008). Ishigooka et al. (2011) introduced this function during the 20 days after heading (hereafter "HD_m26"), and found that there was qualitative relation between HD_m26 and the percentage of first grade rice at the prefecture level, independent of cultivar. The heat degree-days above $26^{\circ} \mathrm{C}$ had also been used in some other existing studies as the index of heat stress causing the emergence of chalky grains (e.g., Lur et al., 2009; Usui et al., 2016). Thus, as an indicator of heat stress intensity affecting the quality of rice grain, we used HD_m26, which is calculated as:

$$
H D_{\_} m 26=\sum_{\mathrm{i}=1}^{20} \max \left(T m_{i}-26,0\right)
$$

where $T m_{i}$ is the daily mean temperature on the $i$ th day from the heading date.

In our previous comparison of HD_m26 and percentage of first grade rice (Ishigooka et al., 2011), the upper limit of the percentage began to decrease when $\mathrm{HD} \_\mathrm{m} 26>20^{\circ} \mathrm{C} \cdot$ days, which roughly corresponds to an average daily mean temperature of $27^{\circ} \mathrm{C}$ during the 20 days after heading, and the percentage was significantly low when HD_m $26>40^{\circ} \mathrm{C} \cdot$ days, roughly corresponding to an average daily mean temperature of $28^{\circ} \mathrm{C}$ during that period. Therefore, we classified the yield based on the degree of quality degradation risk due to high temperature during the early grain-filling period as class A (low risk): $\mathrm{HD}_{-}$ $\mathrm{m} 26<20^{\circ} \mathrm{C} \cdot$ days; class $\mathrm{B}$ (moderate risk): $20^{\circ} \mathrm{C} \cdot$ days $\leq \mathrm{HD}_{-}$ $\mathrm{m} 26<40^{\circ} \mathrm{C} \cdot$ days; or class $\mathrm{C}$ (high risk): HD_m $26 \geq 40^{\circ} \mathrm{C} \cdot$ days.

\subsection{Data needed for the model}

The $\mathrm{H} / \mathrm{H}$ model requires three types of input data for implementation: daily meteorological data, yearly $\mathrm{CO}_{2}$ concentration, and data on several cultivation management practices. In addition, we prepared some geographic information and administrative boundary data for dividing the data sets into geographical regions. Because the $\mathrm{H} / \mathrm{H}$ model was implemented using the second-order mesh, all data used for the implementation of the $\mathrm{H} / \mathrm{H}$ model for this assessment were transformed to match this framework.

\subsubsection{Daily meteorological dataset}

The $\mathrm{H} / \mathrm{H}$ model needs daily mean, maximum and minimum temperatures, downward shortwave radiation, relative humidity, and wind speed as inputs. The original climate change scenarios were obtained from the fifth phase of the Coupled Model Intercomparison Project (CMIP5; Taylor et al., 2012), in which outputs from multiple GCMs simulated for four emission scenarios of representative concentration pathways (RCPs; Moss et al., 2010) are archived. We selected the 18 projected climate change scenarios (6 GCMs $\times 3$ RCPs) listed in Table 1, and obtained their monthly data for the period 1981-2100 containing the elements required for model implementation described above from the CMIP5 portal (http://cmip-pcmdi.llnl.gov/cmip5/). Each original climate change scenario was spatially converted into the common spatial resolution at the second-order mesh standard by the inverse distance-weighted interpolation method. Bias in the original scenarios was corrected by the equidistant cumulative distribution function (CDF) matching method proposed by Li et al. (2010), in which individual CDFs for baseline and future periods were used:

$$
\begin{aligned}
& \tilde{x}=x+F_{o}^{-1}(p)-F_{g b}^{-1}(p) \\
& p=F_{g f}(x)
\end{aligned}
$$

where $\tilde{x}$ is the bias-corrected value, $x$ is the GCM output, $F^{-1}$ o and $F_{g b}^{-1}$ are the inverse of CDFs of the observed data and the

\begin{tabular}{|c|c|c|}
\hline Model name & Modeling center & Institution \\
\hline MIROC5 & MIROC & $\begin{array}{l}\text { Atmosphere and Ocean Research Institute (The University of Tokyo), National Institute for } \\
\text { Environmental Studies, and Japan Agency for Marine-Earth Science and Technology }\end{array}$ \\
\hline MRI-CGCM3 & MRI & Meteorological Research Institute \\
\hline GFDL-CM3 & NOAA GFDL & Geophysical Fluid Dynamics Laboratory \\
\hline HadGEM2-ES & $\begin{array}{l}\text { MOHC } \\
\text { (additional realizations by INPE) }\end{array}$ & $\begin{array}{l}\text { Met Office Hadley Centre (additional HadGEM2-ES realizations contributed by Instituto Nacional } \\
\text { de Pesquisas Espaciais) }\end{array}$ \\
\hline CSIRO-Mk3-6-0 & CSIRO-QCCCE & $\begin{array}{l}\text { Commonwealth Scientific and Industrial Research Organisation in collaboration with the Queensland } \\
\text { Climate Change Centre of Excellence }\end{array}$ \\
\hline BCC-CSM1.1 & $\mathrm{BCC}$ & Beijing Climate Center, China Meteorological Administration \\
\hline
\end{tabular}
GCM data during the 20-year baseline period (1981-2000), $p$ is

Table 1. List of general circulation models (GCMs) used in this study. 
the probability of occurrence of the GCM output within the target period, and $F_{g f}$ is the CDF of the GCM data in the target period (every 20 years). CDFs for all GCMs and observed data were identified for each month and each cell by using each monthly average and standard deviation during every 20 years including the baseline period.

The observed data coordinated with the second-order mesh were derived from the gridded daily meteorological dataset with third-order resolution (approximately $1 \mathrm{~km} \times 1 \mathrm{~km}$ ) developed by the National Institute for Agro-Environmental Sciences, Japan (hereafter "Mesh Meteorological Dataset (NIAES)"), where the observed daily meteorological data at Automated Meteorological Data Acquisition System (AMeDAS) stations are interpolated according to the method developed by Seino (1993). This dataset includes only daily mean, maximum, and minimum temperatures and downward shortwave radiation. The remaining elements required for analyses in this study - relative humidity and wind speed - were also prepared by interpolating the observed data in the same manner as Seino (1993). To conform the observed data to the climate change scenario at spatial and temporal scales during the baseline period, the third-order daily data were averaged by the second-order framework and were then averaged by monthly order. Finally, monthly averages and standard deviations were calculated during the baseline period.

In general, the type of CDF used in the bias correction depends on the characteristics of interannual variability by month in each meteorological element (e.g., Iizumi et al., 2010). We used the normal distribution function for mean, maximum, and minimum temperature, the gamma distribution function for shortwave radiation and wind speed, and the beta distribution function for relative humidity.

Finally, all of the bias-corrected monthly values were converted to daily values by using the weather generator WXGEN (Sharpley and Williams, 1990), which uses stochastic methods to generate daily values from monthly data. Some additional input data required for model implementation were calculated from the generated daily data: the daily mean water temperature was estimated following Kuwagata et al. (2008), and the daily downward longwave radiation (used for the estimation of water temperature) was estimated with the method proposed by Kondo et al. (1991).

\subsection{2 $\mathrm{CO}_{2}$ concentrations in RCPs}

The RCP scenarios were developed and used in the latest (fifth) IPCC report, which was the successor to the Special Report on Emissions Scenarios (Nakicenovic and Swart, 2000) used in the third and fourth assessment reports. There are four types of RCPs with specific radiative forcings: RCP2.6, RCP4.5, RCP6.0, and RCP8.5. The number of each RCP indicates the amount of radiative forcing $\left(\mathrm{W} \mathrm{m}^{-2}\right)$ in 2100 predicted to be produced by the increments of greenhouse gases.

The time series of the annual $\mathrm{CO}_{2}$ concentration for each RCP used in this study were obtained from the Potsdam Institute for Climate Impact Research (Meinshausen et al., 2011) website (http://www.pik-potsdam.de/ mmalte/rcps/; last accessed 17 November 2016). The $\mathrm{CO}_{2}$ concentrations in 2100 were predicted to be $421 \mathrm{ppm}$ for RCP2.6, $538 \mathrm{ppm}$ for RCP4.5, $670 \mathrm{ppm}$ for RCP6.0, and $936 \mathrm{ppm}$ for RCP8.5. We ignored seasonal changes and spatial heterogeneity of $\mathrm{CO}_{2}$ concentration.

\subsubsection{Distribution of paddy fields}

The spatial distribution of paddy fields, which is needed to detect the target cells for the calculation and to sum calculated yield into total production, was derived from the "Land Use Mesh 2006" data set of National Land Numerical Information (Geographical Survey Institute, Ministry of Land, Infrastructure, Transport and Tourism of Japan, http://nlftp.mlit.go.jp/ksj/gml/datalist/KsjTmplt-L03-a.html; last accessed 17 November 2016). In this data set, the land surface is classified into 11 land-use categories, including "paddy field", and the area that each category occupies within each individual cell is based on land-use information in 2006. To match the spatial framework of the calculation unit used in this study, the area of paddy fields in the original grid cells of the third-order resolution was aggregated into the cells of the second-order resolution.

\subsubsection{Cultivars}

Because obtained parameters for the $\mathrm{H} / \mathrm{H}$ model are cultivar-specific, information on the spatial distribution of cultivars for each cell over the study area is required for implementation. We obtained annual data on the areas planted with major rice cultivars by prefecture from statistical yearbooks available on the MAFF website (http://www.maff.go.jp/j/tokei/kouhyou/syokuryo_nenkan/; last accessed 17 November 2016). This dataset identifies the first to third most dominant cultivars and each fraction of cultivated area within the total cultivated area in each prefecture. In this study, the first dominant cultivar in each prefecture was assigned as the predominant cultivar. If that cultivar was not included in the 15 cultivars for which parameters had been estimated, then the second dominant cultivar was selected.

\subsubsection{Nitrogen fertilization}

Because no data are systematically collected in terms of the spatial distribution of yearly nitrogen fertilizer amount for rice cultivation on a national scale, we calculated those values using the statistical data relevant to the consumption of fertilizers available on the MAFF website (http://www.maff.go.jp/j/tokei/kouhyou/noukei/seisanhi_nousan/; last accessed 17 November 2016). In this dataset, the annual amount of various kinds of fertilizer products consumption are summarized for nine regions (Hokkaido, Tohoku, Hokuriku, Kanto-Tosan, Tokai, Kinki, Chugoku, Shikoku, and Kyushu-Okinawa). The amount of inorganic nitrogen input was calculated as the sum of nitrogen components within each fertilizer product. The fractions of nitrogen components within each fertilizer product were obtained from the "Handy Directory of Fertilizer 2009" (MAFF, Food Safety and Consumer Affairs Bureau, 2010). Finally, the annual amounts of inorganic nitrogen input were calculated by region for every year on the assumption that the fractions of nitrogen components within each fertilizer product will remain constant.

\subsubsection{Transplanting date}

The spatial distributions of transplanting date were obtained from a MAFF dataset that provides yearly statistics of yield and the cultivation schedule (dates of sowing, transplanting, heading, and harvesting) of rice, which are summarized by sub-administrative regions called "sub-regions for yield statistics" ("SRYS"; sakugara hyouji chitai in Japanese). The SRYS 
transplanting dates were allocated to each corresponding cell by using the SRYS codes as described by Ishigooka et al. (2011).

\subsection{Validation}

Because Fukui et al. (2015) and Yoshida et al. (2015) validated the performance of the $\mathrm{H} / \mathrm{H}$ model for the estimation of rice phenology and yield, respectively, we performed incremental validation procedures to complement the insufficient parts of those studies. To evaluate the validity of applying the $\mathrm{H} / \mathrm{H}$ model nationwide, we compared the simulated heading date and yield with observed data for each cultivar at a sufficient number of points across Japan where the statistics of rice productivity are available. As the observed data satisfying this condition, we used data obtained from the nationwide crop survey for crop statistics (CSCS) for the period between 1995 and 2011, extracted from the standard lot survey by the Production, Marketing and Consumption Statistics Division of MAFF. Details of this dataset are described by Fukui et al. (2017).

Input daily meteorological data at every survey point were obtained from the Mesh Meteorological Dataset (NIAES) by extracting the corresponding third-order mesh with the location of each survey point in longitude and latitude. If the survey point differed in altitude by $>30 \mathrm{~m}$ from the third-order mesh, it was excluded from the comparison. $\mathrm{CO}_{2}$ concentration data were obtained from the World Data Center for Greenhouse Gases (http: / / ds.data.jma.go.jp/gmd/wdcgg/wdcgg.html; last accessed 17 November 2016). Annual average $\mathrm{CO}_{2}$ concentrations measured at Ryori station, near Ofunato City, Japan $\left(39.03^{\circ} \mathrm{N}\right.$, $141.82^{\circ} \mathrm{E}, 260 \mathrm{~m}$ a.s.1.), were used for all survey points, as the differences among locations in Japan are negligible at the annual scale. Nitrogen fertilizer inputs were obtained from the dataset of regional nitrogen inputs described in section 2.2.5 according the location of the field. Inputs were divided into three fractions: $8 / 14$ of the total applied as basal fertilizer and 3/14 applied at each of DVI $=1.3$ and 1.6 as supplemental fertilizer. Cultivar, transplanting date, and seedling number were obtained from the record in the survey data. We set available soil nitrogen as $7 \mathrm{~g} \mathrm{~m}^{-2}$, a planting density of $20 \mathrm{~m}^{-2}$, and 3 plants per hill.

We also calculated yield from the observed phenology to evaluate whether the major cause of error in the estimation of yield is the uncertainty in phenology estimates. We first ran the model to estimate daily DVI at each site, and compared dates of heading and harvest with the observed dates to derive a correction factor for the model estimates. Then the model was run again, and the daily increment of DVI (i.e., DVR) was corrected by multiplying the correction factor by the simulated DVR.

\subsection{Impact assessment and adaptation effect}

In the simulation for impact assessments and the subsequent analyses, the $\mathrm{H} / \mathrm{H}$ model was implemented with daily meteorological datasets derived from 18 climate change scenarios described in section 2.2.1 within the period from 1981 to 2100 as driving forces, under the $\mathrm{CO}_{2}$ concentration defined by each RCP (see section 2.2.2) for every year. To examine the effect of shifting the cropping calendar as an adaptation measure to reduce the negative impact of climate change on rice productivity, we ran the simulations for multiple transplanting dates. In each simulation, the transplanting date (section 2.2.6) in 2006 was determined as the standard transplanting date by SRYS and was shifted at 7-day intervals within the range of -70 to +70 days from the standard transplanting date as the starting point; that is, calculations were based on 21 patterns of transplanting date for every year.

The model was run in the grid cells where the areal proportion of paddy fields (section 2.2.3) was larger than $1 \%$ of total land area within the cell. Of the total 4662 cells, 3650 were selected by this criterion as the calculation target.

Because we do not account for any land-use change or the expansion/reduction of rice cultivation area caused by the predicted temperature increase in this study, we assumed the distribution and areas of paddy fields to be fixed to the conditions in 2006 for the entire study period. Also, predominant cultivars (section 2.2.4) and yearly nitrogen inputs (section 2.2.5) for each cell were assumed to be fixed to those in 2006 to reveal the effect of climate change on rice productivity and quality. The schedule and amount of nitrogen input were applied as in the validation study (8/14 of yearly total at DVI $=0,3 / 14$ at DVI $=1.3,3 / 14$ at DVI $=1.6$ ). Likewise, we used available soil nitrogen $=7 \mathrm{~g} \mathrm{~m}^{-2}, 20$ plants $\mathrm{m}^{-2}$, and 3 plants per hill as input for all areas and times.

To investigate the effect of shifting transplanting dates as an adaptation measure while taking both rice quantity and quality into consideration, we tested two methods of selecting the optimal transplanting date under the given climatic conditions. In the first method, the optimal transplanting date is the date when maximum yield is achieved without taking quality into consideration (adaptation 1). In the second method, it is the date of maximum yield under the condition that the quality does not decline, that is, the date maximizing the class A yield (adaptation 2). These optimal transplanting dates were determined for every 20-year interval throughout the target period. Thus, the transplanting date with the largest 20-year average total yield was selected as the optimal transplanting date for adaptation 1 . Likewise, the date with the largest 20-year average class A yield (section 2.1.4) was selected as the optimal transplanting date for adaptation 2. We evaluated the impact of projected climate change on rice quantity and quality, as well as the effect of the adaptation measure to overcome harms, by comparing the results based on both types of adaptation with those based on the standard (current) transplanting date (no adaptation).

\section{Results and Discussion}

\subsection{Validation}

We first compared the simulated heading date with the observed one for each cultivar to evaluate the validity of phenology estimation. The mean bias and root mean square error (RMSE) of periods from transplanting date (given) to heading date (simulated) are listed in Table 2. The mean biases ranged from -3.40 to +4.70 days among cultivars (average, -0.4 days) and the RMSEs ranged from 3.04 to 6.02 days (average, 4.0 days). Although some cultivars had relatively large mean bias and RMSE values, such as Kirara 397 (4.70 and 6.02) and Aichinokaori ( -3.40 and 4.99), their percentage of the observed duration from transplanting to heading was less than $10 \%$, and they were within 7 days, which is the interval of shifting transplanting date in this study. The RMSEs calculated in this study are comparable to the results of 
Fukui et al. (2015), which ranged from 2.73 to 4.90 days (average, 3.4 days) and were calculated from another observed dataset. The biases tended to be negative, as was the case in the study by Fukui et al. (2017), in which new phenological models using water temperature as input instead of air temperature during the early growing period were validated using the CSCS data, and the biases were estimated to be negative even if the RMSEs were small.

The performance of yield calculation was also evaluated by mean bias and RMSE (Table 2). The mean bias of each cultivar ranged from -1.08 to $+0.21 \mathrm{tha}^{-1}$ (average, $-0.52 \mathrm{t} \mathrm{ha}^{-1}$ ), and their percentage of the observed yield ranged from $-19.2 \%$ to $+4.0 \%$ (average, $-9.3 \%$ ). RMSEs ranged from 0.78 to $1.56 \mathrm{t}$ $\mathrm{ha}^{-1}$ (average, $1.08 \mathrm{tha}^{-1}$ ), and their percentage of the observed yield ranged from $14.3 \%$ to $27.8 \%$ (average, 19.2\%). These results indicate that the model tends to underestimate the brown rice yield by roughly $10 \%$, and the estimated values have uncertainties of roughly $20 \%$ of observed yield. Comparing these biases and RMSEs with those from the experiments using fixed DVI (Table 2), we did not note remarkable differences between them in either biases or RMSEs, which suggests that it is difficult to attribute the estimation error to inaccuracy in the estimation of phenological changes. In general, crop yield depends strongly on many site-specific conditions, such as available nitrogen in the soil, water management, and amount and timing of fertilizer. In this experiment, all of these model inputs were averaged or unified by region. Moreover, other factors that influence the yield, such as disease, pests, and typhoon damage, are not included in the model. Owing to these many sources of uncertainty in the calculations, the model tends to have relatively large error in the estimation of yield at the plot scale.

To evaluate the validity of interannual variability of estimated yield at the regional scale, we compared the temporal change of estimated yield with that of observed yield, both of which were averaged within the nine regions of Japan (Fig. 2). Overall, the estimated yields corresponded well with observed yields in both absolute amount and yearly variation, although the difference was relatively large in Hokkaido. Except for Hokkaido, the RMSEs ranged from 0.33 to $0.45 \mathrm{t} \mathrm{ha}^{-1}$ and their percentage of the observed yield were less than $10 \%$, while the correlation coefficients were low where observed interannual variation was small. In regions except Hokkaido, a clear decreasing trend was found in the estimated yield throughout the period, while there is no apparent trend in the observed yield. Similar characteristics were reported by Katayanagi et al. (2016), who attributed the difference in the long-term trend between time series of rice yield estimated by the DNDC-Rice model and the observed yield to the process of nitrogen uptake by rice plants. In the $\mathrm{H} / \mathrm{H}$ model, nitrogen uptake also makes a large contribution to the increase in biomass, and therefore the estimation accuracy could be improved by modifying the process of nitrogen uptake. We could not identify the main cause of the relatively large underestimation in Hokkaido in this study, but the relative variability seems to be reproduced sufficiently well for long-term assessment.

Our validation analyses revealed that the $\mathrm{H} / \mathrm{H}$ model can sufficiently reproduce both phenological development and yield formation under changing climate at the regional scale, and therefore the model is applicable for the objectives of this study as an impact assessment model.

\subsection{Impact of climate change on rice yield and quality}

The $\mathrm{H} / \mathrm{H}$ model was implemented using 18 projected climate change scenarios (6 GCMs $\times 3$ RCPs) from 1981 to 2100 based on 21 patterns of transplanting date. To assess the impact of projected $\mathrm{CO}_{2}$ and temperature change on estimated yield in the mid and late 21 st century on the basis of standard transplanting date (no adaptation), we averaged yields for the periods 1981-2000 ("baseline period"), 2031-2050 ("mid period"), and 20812100 ("late period") in each cell. We aggregated the yields to the nationwide production levels in the mid and late periods, all of which are expressed as the percentage of that of the baseline

Table 2. Validation results for the 15 cultivars.

\begin{tabular}{|c|c|c|c|c|c|c|c|c|}
\hline \multirow{3}{*}{ Cultivars } & \multirow{3}{*}{$\begin{array}{c}\text { No. } \\
\text { Records }\end{array}$} & \multicolumn{3}{|c|}{ Heading date $[\text { days }]^{1)}$} & \multicolumn{4}{|c|}{ Brown rice yield $\left[\mathrm{t} \mathrm{ha}^{-1}\right]$} \\
\hline & & \multirow[t]{2}{*}{ Bias } & \multicolumn{2}{|c|}{ RMSE } & \multicolumn{2}{|c|}{ Calculated DVI } & \multicolumn{2}{|c|}{ Fixed DVI } \\
\hline & & & This study & Fukui et al. ${ }^{2)}$ & Bias & RMSE & Bias & RMSE \\
\hline Kirara 397 & 334 & 4.70 & 6.02 & 4.90 & -1.03 & 1.50 & -1.03 & 1.44 \\
\hline Akitakomachi & 605 & -0.49 & 3.81 & 3.65 & -0.26 & 0.93 & -0.19 & 0.93 \\
\hline Haenuki & 191 & 1.63 & 3.48 & 4.12 & -0.60 & 1.06 & -0.61 & 1.06 \\
\hline Hitomebore & 636 & -1.92 & 4.03 & 4.87 & -0.10 & 0.81 & 0.04 & 0.82 \\
\hline Kinuhikari & 863 & -1.14 & 3.94 & 2.92 & -0.27 & 0.85 & -0.26 & 0.84 \\
\hline Koshihikari & 4461 & -1.67 & 4.35 & 4.17 & 0.21 & 0.89 & 0.26 & 0.89 \\
\hline Koshiibuki & 35 & -1.77 & 3.05 & 3.32 & -1.08 & 1.31 & -0.93 & 1.15 \\
\hline Asahinoyume & 96 & -1.23 & 3.81 & 3.33 & -0.78 & 1.19 & -0.75 & 1.18 \\
\hline Aichinokaori & 85 & -3.40 & 4.99 & 3.04 & -0.20 & 0.78 & -0.12 & 0.78 \\
\hline Hinohikari & 1797 & -1.65 & 3.69 & 2.73 & -0.53 & 1.01 & -0.51 & 0.99 \\
\hline Hoshinoyume & 160 & 2.87 & 4.30 & 3.67 & -0.65 & 1.21 & -0.90 & 1.40 \\
\hline Nanatsuboshi & 97 & 0.35 & 3.30 & 2.92 & -1.08 & 1.56 & -1.16 & 1.59 \\
\hline Masshigura & 54 & 1.46 & 5.02 & 3.47 & -0.42 & 1.07 & -0.51 & 1.03 \\
\hline Tsugaruroman & 111 & -2.13 & 3.55 & 2.21 & -0.65 & 1.17 & -0.49 & 1.06 \\
\hline Yumetsukushi & 143 & -1.01 & 3.04 & 1.58 & -0.41 & 0.82 & -0.37 & 0.83 \\
\hline
\end{tabular}



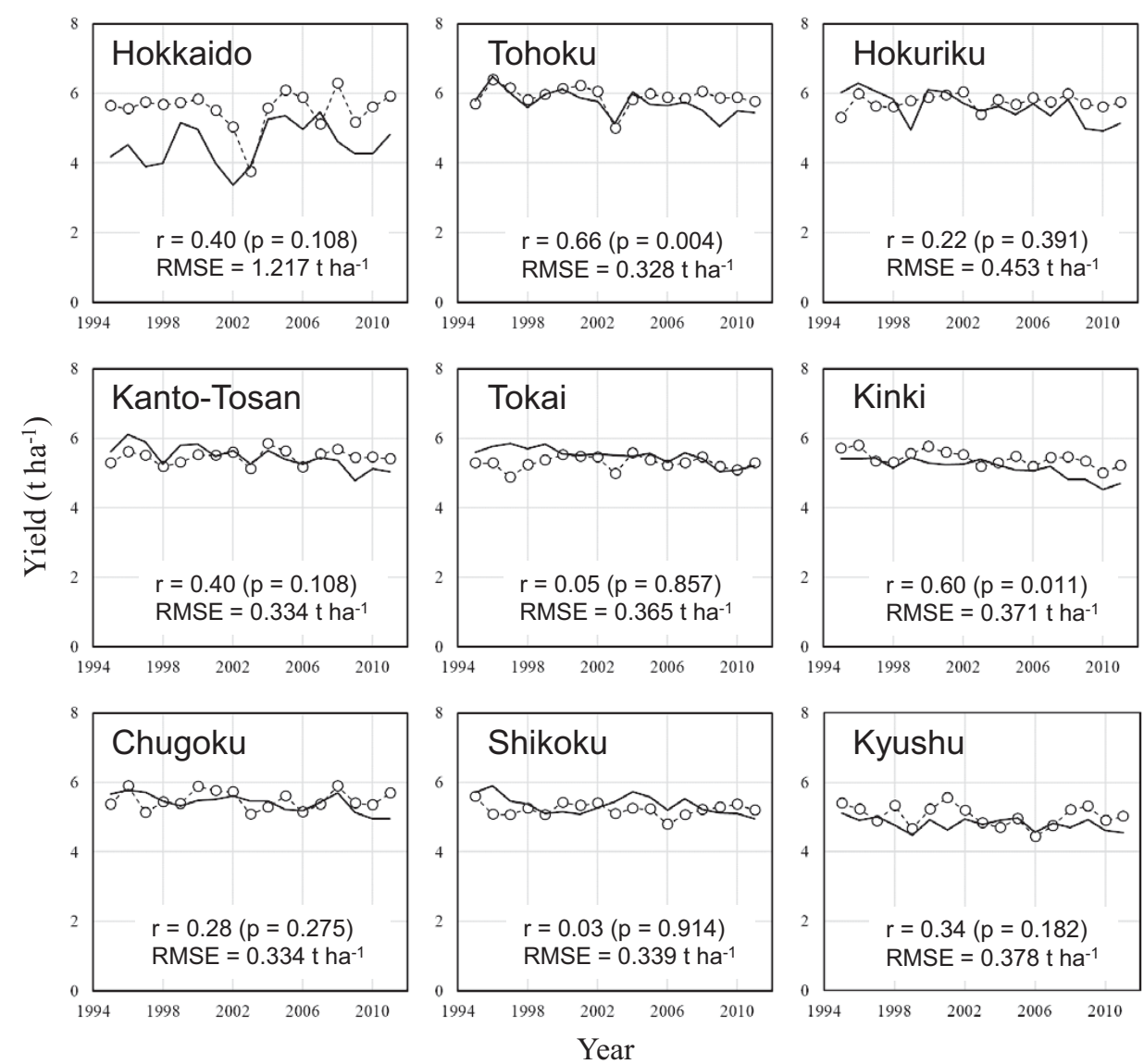

\section{-o- Observed -Estimated}

Fig. 2. Temporal changes of calculated yield (-) and observed yield (- $\left.-_{-}^{-}\right)$averaged within each region from 1995 to 2011. In the averaging, we excluded data within the prefecture if the ratio of damage due to strong wind and flood obtained from the crop statistics (MAFF, 2015) was $>20 \%$. $r$ (correlation coefficient), $p$ ( $p$-value at significance level), and RMSE (Root Mean Square Error) between the calculated and the observed yield are presented in each figure.

period with no adaptation. Finally, we calculated the percentage of area where the yield was estimated to increase from the baseline period (hereafter, "increasing area") and that where the yield was estimated to decrease from the baseline period (hereafter, "decreasing area") in both the mid and late periods.

During the mid period, $\mathrm{CO}_{2}$ concentration was predicted to be $439.3 \mathrm{ppm}$ for RCP2.6, 462.1 ppm for RCP4.5, and $493.4 \mathrm{ppm}$ for RCP8.5 (Table 3). The change of mean temperature ranged from +0.6 to $+2.6^{\circ} \mathrm{C}$ (average, $+1.6^{\circ} \mathrm{C}$ ) in $\mathrm{RCP} 2.6$, from +1.1 to $+2.7^{\circ} \mathrm{C}$ (average, $+1.7^{\circ} \mathrm{C}$ ) in $\mathrm{RCP} 4.5$, and from +1.1 to $+3.0^{\circ} \mathrm{C}$ (average, $+1.9^{\circ} \mathrm{C}$ ) in $\mathrm{RCP} 8.5$. In this period, the differences in temperature among RCPs are not large, whereas the differences among GCMs within each RCP are relatively large. The nationwide total rice production levels were estimated to increase from the baseline period in all climate change scenarios, ranging from $110 \%$ to $118 \%$ (average, 114\%) relative to that of the baseline period in RCP2.6, from $111 \%$ to $121 \%$ (average, $117 \%$ ) in RCP4.5, and from $112 \%$ to $124 \%$ (average, 119\%) in RCP8.5. The increasing area was markedly larger than the decreasing area in all climate change scenarios, although a relatively large decreasing area was found in some cases, such as GFDL-CM3 under all RCPs and HadGEM2-ES under $\mathrm{RCP} 2.6$, in which the temperature increases were relatively large. In the case of HadGEM2-ES under RCP8.5, the decreasing area was smaller than that of under RCP2.6 despite the fact that the temperature increases were similar, suggesting that the increase in $\mathrm{CO}_{2}$ concentration greatly affected yield estimation through the activation of photosynthesis due to the $\mathrm{CO}_{2}$ fertilization effect.

During the late period, $\mathrm{CO}_{2}$ concentration was predicted to be $425.9 \mathrm{ppm}$ for RCP2.6, $534.3 \mathrm{ppm}$ for RCP4.5, and $850.1 \mathrm{ppm}$ for RCP8.5 (Table 3). The change in mean temperature ranged from +1.1 to $+3.0^{\circ} \mathrm{C}$ (average, $+1.8^{\circ} \mathrm{C}$ ) in $\mathrm{RCP} 2.6$, from +1.9 to $+4.1^{\circ} \mathrm{C}$ (average, $+2.8^{\circ} \mathrm{C}$ ) in $\mathrm{RCP} 4.5$, and from +3.7 to $+6.7^{\circ} \mathrm{C}$ (average, $+4.9^{\circ} \mathrm{C}$ ) in $\mathrm{RCP} 8.5$. In this period, the differences in both temperature and $\mathrm{CO}_{2}$ concentration among RCPs were very large, and the differences among GCMs within each RCP were large. Therefore, the uncertainty in the projection of temperature seems to be greater in the late period. The nationwide total production levels were estimated to increase from the baseline period in most climate change scenarios, except GFDL-CM3 under RCP8.5, with increases ranging from $107 \%$ to $117 \%$ (average, $113 \%$ ) in RCP2.6, from $111 \%$ to $129 \%$ (average, $121 \%$ ) in RCP4.5, and from $99 \%$ to $140 \%$ (average, 122\%) in RCP8.5. The increasing area was estimated to be larger than the decreasing area in all climate change scenarios, even though the nationwide total production was estimated to decrease (GFDL-CM3, RCP8.5).

To identify the geographic distribution of changes in yield 
Table 3. $\mathrm{CO}_{2}$ concentrations, temperature increases, and percentages of estimated total rice production and increasing and decreasing areas relative to the baseline period for each climate change scenario during the baseline (only $\mathrm{CO}_{2}$ ), mid, and late periods.

\begin{tabular}{|c|c|c|c|c|c|c|c|c|c|c|c|c|}
\hline \multirow{2}{*}{$\mathrm{RCP}$} & \multirow{2}{*}{ GCM } & \multirow{2}{*}{$\begin{array}{c}\frac{1981-2000}{\left[\mathrm{CO}_{2}\right]^{1)}} \\
(\mathrm{ppm})\end{array}$} & \multicolumn{5}{|c|}{$2031-2050$} & \multicolumn{5}{|c|}{$2081-2100$} \\
\hline & & & $\begin{array}{l}{\left[\mathrm{CO}_{2}\right]^{1)}} \\
(\mathrm{ppm})\end{array}$ & $\begin{array}{c}\left.\mathrm{dTm}^{2}\right) \\
\left({ }^{\circ} \mathrm{C}\right)\end{array}$ & $\begin{array}{c}\text { Relative } \\
\text { production }^{3)}\end{array}$ & $\begin{array}{c}\text { Increasing } \\
\text { area }^{4)}\end{array}$ & $\begin{array}{c}\text { Decreasing } \\
\text { area }^{5)}\end{array}$ & $\begin{array}{l}{\left[\mathrm{CO}_{2}\right]^{1)}} \\
(\mathrm{ppm})\end{array}$ & $\begin{array}{c}\mathrm{dTm}^{2)} \\
\left({ }^{\circ} \mathrm{C}\right)\end{array}$ & $\begin{array}{c}\text { Relative } \\
\text { production }^{3)}\end{array}$ & $\begin{array}{c}\text { Increasing } \\
\text { area }^{4)}\end{array}$ & $\begin{array}{c}\text { Decreasing } \\
\text { area }^{5)}\end{array}$ \\
\hline \multirow{6}{*}{$\mathrm{RCP} 2.6$} & MIROC5 & \multirow{6}{*}{353.8} & \multirow{6}{*}{439.3} & +1.5 & $118 \%$ & $100 \%$ & $0 \%$ & \multirow{6}{*}{425.9} & +1.8 & $115 \%$ & $98 \%$ & $2 \%$ \\
\hline & MRI-CGCM3 & & & +0.6 & $115 \%$ & $100 \%$ & $0 \%$ & & +1.1 & $117 \%$ & $100 \%$ & $0 \%$ \\
\hline & GFDL-CM3 & & & +2.6 & $110 \%$ & $72 \%$ & $28 \%$ & & +3.0 & $107 \%$ & $56 \%$ & $44 \%$ \\
\hline & HadGEM2-ES & & & +2.1 & $111 \%$ & $87 \%$ & $13 \%$ & & +2.0 & $113 \%$ & $91 \%$ & $9 \%$ \\
\hline & CSIRO-Mk3-6-0 & & & +1.5 & $114 \%$ & $98 \%$ & $2 \%$ & & +1.9 & $112 \%$ & $88 \%$ & $12 \%$ \\
\hline & BCC-CSM1.1 & & & +1.2 & $116 \%$ & $100 \%$ & $0 \%$ & & +1.3 & $115 \%$ & $100 \%$ & $0 \%$ \\
\hline \multirow{6}{*}{$\mathrm{RCP} 4.5$} & MIROC5 & \multirow{6}{*}{353.8} & \multirow{6}{*}{462.1} & +1.7 & $121 \%$ & $99 \%$ & $1 \%$ & \multirow{6}{*}{534.3} & +2.5 & $126 \%$ & $100 \%$ & $0 \%$ \\
\hline & MRI-CGCM3 & & & +1.1 & $119 \%$ & $100 \%$ & $0 \%$ & & +1.9 & $129 \%$ & $100 \%$ & $0 \%$ \\
\hline & GFDL-CM3 & & & +2.7 & $111 \%$ & $80 \%$ & $20 \%$ & & +4.1 & $111 \%$ & $66 \%$ & $34 \%$ \\
\hline & HadGEM2-ES & & & +2.0 & $115 \%$ & $94 \%$ & $6 \%$ & & +3.3 & $118 \%$ & $85 \%$ & $15 \%$ \\
\hline & CSIRO-Mk3-6-0 & & & +1.5 & $117 \%$ & $100 \%$ & $0 \%$ & & +2.9 & $118 \%$ & $92 \%$ & $8 \%$ \\
\hline & BCC-CSM1.1 & & & +1.5 & $119 \%$ & $99 \%$ & $1 \%$ & & +2.1 & $126 \%$ & $100 \%$ & $0 \%$ \\
\hline \multirow{6}{*}{ RCP8.5 } & MIROC5 & \multirow{6}{*}{353.8} & \multirow{6}{*}{493.4} & +1.8 & $124 \%$ & $100 \%$ & $0 \%$ & \multirow{6}{*}{850.1} & +4.5 & $131 \%$ & $94 \%$ & $6 \%$ \\
\hline & MRI-CGCM3 & & & +1.1 & $124 \%$ & $100 \%$ & $0 \%$ & & +3.7 & $140 \%$ & $100 \%$ & $0 \%$ \\
\hline & GFDL-CM3 & & & +3.0 & $112 \%$ & $81 \%$ & $19 \%$ & & +6.7 & $99 \%$ & $51 \%$ & $49 \%$ \\
\hline & HadGEM2-ES & & & +2.2 & $117 \%$ & $95 \%$ & $5 \%$ & & +5.6 & $113 \%$ & $65 \%$ & $35 \%$ \\
\hline & CSIRO-Mk3-6-0 & & & +1.7 & $120 \%$ & $99 \%$ & $1 \%$ & & +5.1 & $119 \%$ & $71 \%$ & $29 \%$ \\
\hline & BCC-CSM1.1 & & & +1.7 & $120 \%$ & $100 \%$ & $0 \%$ & & +4.0 & $130 \%$ & $91 \%$ & $9 \%$ \\
\hline
\end{tabular}

${ }^{1)} \mathrm{CO}_{2}$ concentration in atmosphere.

${ }^{2)}$ Differences in the mean temperature from the baseline period (1981-2000).

3) Percentage of the nationwide total rice production relative to baseline period (1981-2000).

4) Percentage of area where the yield increased from the baseline period (1981-2000).

5) Percentage of area where the yield decreased from the baseline period (1981-2000).
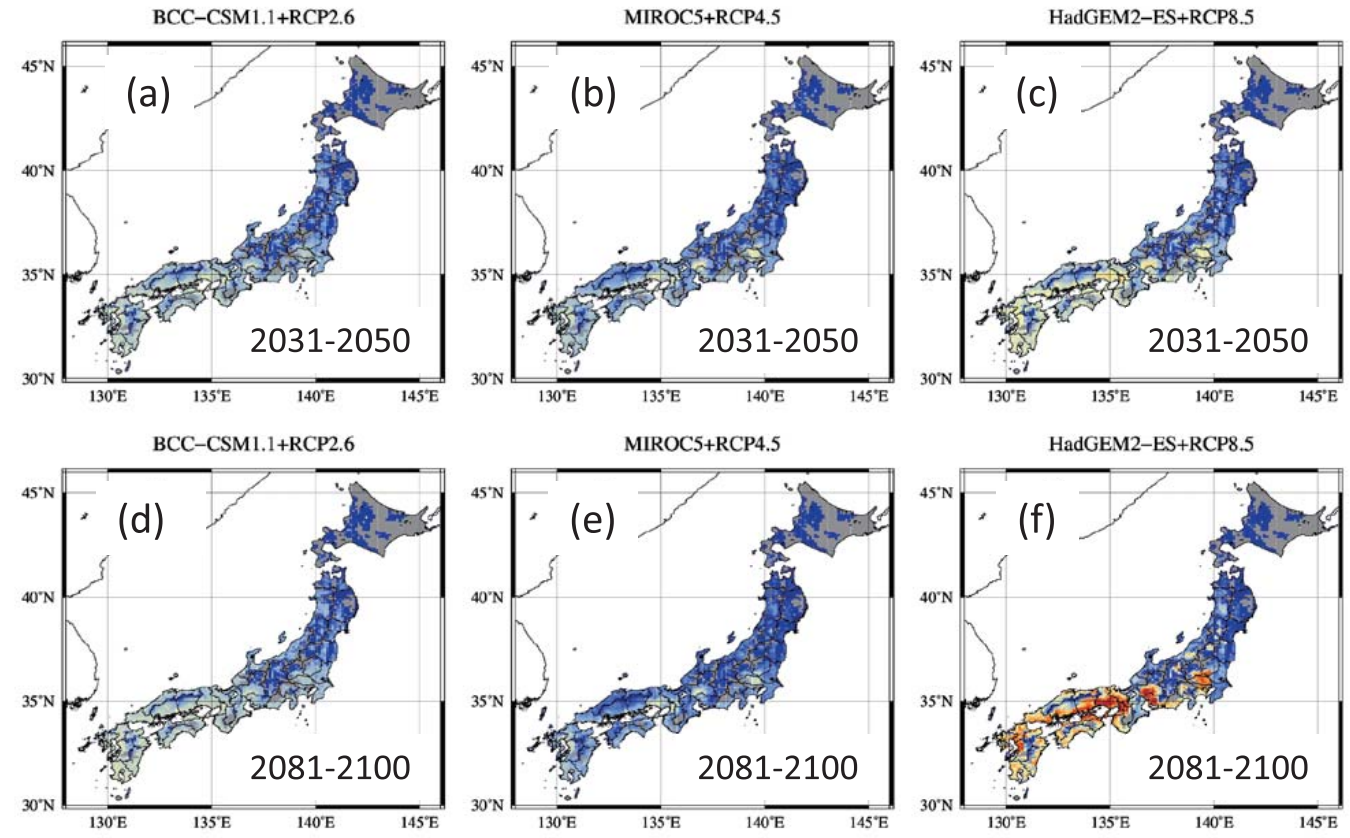

60

80

100

120

$140(\%)$

Fig. 3. Distribution maps of percentage of 20 -year average of total yield relative to that in the baseline period (1981-2000). (a-c) Mid period (2031-2050) and (d-f) late period (2081-2100) calculated using three climate change scenarios (BCC-CSM1.1 + RCP2.6, MIROC5 + RCP4.5, and HadGEM2-ES + RCP8.5).

under contrasting climate projections, we selected three climate change scenarios as examples (hereafter "sample scenarios"): BCC-CSM1.1 + RCP2.6 as the case of small temperature increase $\left(+1.3^{\circ} \mathrm{C}\right.$ in the late period), MIROC5 $+\mathrm{RCP} 4.5$ as the case of average temperature increase $\left(+2.5^{\circ} \mathrm{C}\right.$ in the late period), and HadGEM2-ES + RCP8.5 as the case of large temperature increase $\left(+5.6^{\circ} \mathrm{C}\right.$ in the late period). Additionally, distribution maps by all 18 climate scenarios are shown in the supplemental information (Supplement Figure S1-S16).

The distribution maps of yield in the mid and late periods for 
the three sample scenarios are presented in Fig. 3 (all results are shown in Fig. S1(mid-period) and S2(late-period)). In the mid period, yield was estimated to increase in most areas, especially in the northeastern and northern parts of Japan (Fig. 3a-c). In the late period, similar characteristics were found in the case of BCC-CSM1.1 + RCP2.6 and MIROC5 + RCP4.5 (Fig. 3d, e). In the case of HadGEM2-ES + RCP8.5, however, areas with remarkable yield decreases were found in inland basins and plains in south-central Japan (Fig. 3f), where extremely high temperatures causing heat injuries in crops have emerged frequently even under present climatic conditions.

The major characteristics of changes in yield under the projected climate change scenarios in this study seem to be in agreement with those from previous studies (e.g., Horie et al., 1995b; Hayashi et al., 2001; Iizumi et al., 2011), whereas the increasing trend seems to be stronger than previous estimates. In the estimation of yield in the $\mathrm{H} / \mathrm{H}$ model, the elevation of $\mathrm{CO}_{2}$ concentration leads to a yield increase due to the $\mathrm{CO}_{2}$ fertilization effect, whereas the temperature rise leads to a yield decrease due to the shortened growing period. These two factors occur simultaneously, resulting in no remarkable change in yield in western Japan (Fig. 3a-e). In addition, extremely high temperatures cause an increase in spikelet sterility that leads to a significant yield decrease (Fig. 3f). There are uncertainties in the crop models under increasing temperatures and $\mathrm{CO}_{2}$ concentrations (Li et al., 2015). A recent summary of free-air $\mathrm{CO}_{2}$ enrichment experiments on rice in multiple environments demonstrated a strong negative interaction between temperature and $\mathrm{CO}_{2}$ on grain yield (Hasegawa et al., 2016). However, the $\mathrm{H} / \mathrm{H}$ model is still not capable of reproducing the interaction, so the current estimates of $\mathrm{CO}_{2}$ fertilization effects may be too optimistic.

The calculated yield was classified as class A, B, or C from the degree of quality degradation risk caused by being exposed to high temperatures within the early ripening period, as represented by the HD_m26 value for each year. The 20-year average of total production (the same values as presented in Table 3) and the percentage of each class in the baseline, mid, and late periods are presented in Table 4. As noted above, the total production was estimated to increase in most cases, whereas the proportion of components of each class differed widely among the climate change scenarios in both the mid and late periods. In the baseline period, class A production accounted for about $90 \%$ of total production, with a very small percentage as class $\mathrm{C}$. In the mid and late periods, the percentage of class A was estimated to decrease from those in the baseline period in all cases, ranging from $30.4 \%$ to $82.9 \%$ (average, $60.0 \%$ ) in the mid period and from $1.1 \%$ to $77.7 \%$ (average, $39.2 \%$ ) in the late period.

The decrease in the percentage of class A production seems to be strongly associated with the temperature increase, and there is an apparent negative correlation between them (Fig. 4). From this relationship, we see that the percentage of class A production is expected to decrease to about $55 \%$ of total production when the temperature was assumed to increase by $2^{\circ} \mathrm{C}$ relative to the baseline period and to about $20 \%$ of total production with a $4^{\circ} \mathrm{C}$ increase. It is worth noting, however, that a recent free-air $\mathrm{CO}_{2}$ enrichment study on rice demonstrated that the heat-induced decline in grain appearance quality is exacerbated by elevated $\mathrm{CO}_{2}$ concentration (Usui et al., 2016). Because the $\mathrm{H} / \mathrm{H}$ model does not account for the negative effect of $\mathrm{CO}_{2}$, the reduction in class A yield with increasing temperatures might be even greater if the $\mathrm{CO}_{2}$ effect were taken into account.

Figure 5 shows the spatial distribution of the 20-year averages of class A yield in the mid and late periods for the sample scenarios, all of which are expressed as the percentage relative to that of total yield in the baseline period (see Fig. S3(mid-period) and S4(late-period) for all results corresponding with Fig. 5). The areas with low values are mainly distributed in the plains and inland basins from east to west Japan, and their northern limit expands northward along with

Table 4. Relative rice production and percentage of each class based on no adaptation for each climate change scenario during the baseline, mid, and late periods.

\begin{tabular}{|c|c|c|c|c|c|c|c|c|c|c|c|c|c|}
\hline \multirow{3}{*}{$\mathrm{RCP}$} & \multirow{3}{*}{ GCM } & \multicolumn{4}{|c|}{$1981-2000$} & \multicolumn{4}{|c|}{ 2031-2050 } & \multicolumn{4}{|c|}{$2081-2100$} \\
\hline & & \multirow{2}{*}{$\begin{array}{c}\text { Relative } \\
\text { production }{ }^{1)} \\
(\%)\end{array}$} & \multicolumn{3}{|c|}{ Percentage of each class } & \multirow{2}{*}{$\begin{array}{c}\text { Relative } \\
\text { production }{ }^{1)} \\
(\%)\end{array}$} & \multicolumn{3}{|c|}{ Percentage of each class } & \multirow{2}{*}{$\begin{array}{c}\text { Relative } \\
\text { production }^{1)} \\
(\%)\end{array}$} & \multicolumn{3}{|c|}{ Percentage of each class } \\
\hline & & & $\begin{array}{c}\text { Class A } \\
(\%)\end{array}$ & $\begin{array}{c}\text { Class B } \\
(\%)\end{array}$ & $\begin{array}{c}\text { Class C } \\
(\%)\end{array}$ & & $\begin{array}{c}\text { Class A } \\
(\%)\end{array}$ & $\begin{array}{c}\text { Class B } \\
(\%)\end{array}$ & $\begin{array}{c}\text { Class C } \\
(\%)\end{array}$ & & $\begin{array}{c}\text { Class A } \\
(\%)\end{array}$ & $\begin{array}{c}\text { Class B } \\
(\%)\end{array}$ & $\begin{array}{c}\text { Class C } \\
(\%)\end{array}$ \\
\hline \multirow{6}{*}{$\mathrm{RCP} 2.6$} & MIROC5 & 100.0 & 90.1 & 7.9 & 2.1 & 118.4 & 67.8 & 21.2 & 11.0 & 115.5 & 63.3 & 22.3 & 14.4 \\
\hline & MRI-CGCM3 & 100.0 & 89.8 & 8.8 & 1.4 & 114.6 & 82.9 & 14.1 & 3.0 & 117.0 & 77.7 & 17.2 & 5.1 \\
\hline & GFDL-CM3 & 100.0 & 90.2 & 8.6 & 1.2 & 110.1 & 35.3 & 26.0 & 38.6 & 106.9 & 28.2 & 23.9 & 47.9 \\
\hline & HadGEM2-ES & 100.0 & 89.2 & 8.6 & 2.2 & 111.3 & 53.5 & 24.1 & 22.4 & 113.5 & 59.8 & 23.7 & 16.5 \\
\hline & CSIRO-Mk3-6-0 & 100.0 & 90.6 & 7.4 & 2.0 & 114.2 & 65.0 & 21.8 & 13.2 & 112.2 & 59.5 & 22.3 & 18.2 \\
\hline & BCC-CSM1.1 & 100.0 & 89.6 & 8.6 & 1.8 & 116.3 & 74.6 & 15.7 & 9.8 & 115.3 & 72.2 & 19.6 & 8.2 \\
\hline \multirow{6}{*}{ RCP4.5 } & MIROC5 & 100.0 & 89.9 & 8.0 & 2.2 & 120.7 & 64.1 & 20.2 & 15.8 & 126.4 & 48.1 & 26.1 & 25.7 \\
\hline & MRI-CGCM3 & 100.0 & 90.0 & 8.6 & 1.5 & 118.7 & 79.9 & 15.6 & 4.5 & 129.0 & 66.8 & 22.7 & 10.5 \\
\hline & GFDL-CM3 & 100.0 & 90.3 & 8.5 & 1.2 & 110.8 & 33.8 & 25.3 & 40.9 & 110.7 & 15.5 & 17.8 & 66.7 \\
\hline & HadGEM2-ES & 100.0 & 89.4 & 8.2 & 2.3 & 114.9 & 54.1 & 27.1 & 18.8 & 118.1 & 30.1 & 25.6 & 44.3 \\
\hline & CSIRO-Mk3-6-0 & 100.0 & 90.7 & 7.5 & 1.9 & 117.0 & 65.4 & 19.7 & 15.0 & 118.3 & 40.4 & 23.8 & 35.8 \\
\hline & BCC-CSM1.1 & 100.0 & 89.7 & 8.5 & 1.8 & 119.3 & 67.9 & 19.6 & 12.5 & 126.1 & 56.6 & 24.2 & 19.3 \\
\hline \multirow{6}{*}{ RCP8.5 } & MIROC5 & 100.0 & 90.0 & 8.0 & 2.0 & 123.7 & 57.9 & 25.0 & 17.1 & 131.1 & 17.6 & 20.9 & 61.4 \\
\hline & MRI-CGCM3 & 100.0 & 89.9 & 8.5 & 1.5 & 123.5 & 76.1 & 17.5 & 6.4 & 140.4 & 33.7 & 25.5 & 40.8 \\
\hline & GFDL-CM3 & 100.0 & 90.1 & 8.7 & 1.2 & 112.2 & 30.4 & 26.6 & 43.0 & 99.1 & 1.1 & 5.1 & 93.9 \\
\hline & HadGEM2-ES & 100.0 & 89.2 & 8.4 & 2.4 & 116.9 & 49.1 & 25.8 & 25.1 & 112.5 & 7.2 & 12.8 & 80.0 \\
\hline & CSIRO-Mk3-6-0 & 100.0 & 90.7 & 7.4 & 1.9 & 119.9 & 58.0 & 21.6 & 20.4 & 118.7 & 8.6 & 12.0 & 79.4 \\
\hline & BCC-CSM1.1 & 100.0 & 89.7 & 8.5 & 1.8 & 120.4 & 63.9 & 21.9 & 14.1 & 130.1 & 19.8 & 20.9 & 59.3 \\
\hline
\end{tabular}

${ }^{1)}$ Percentage of the nationwide total rice production relative to that of baseline period (1981-2000) on the basis of standard transplanting date (no adaptation). 


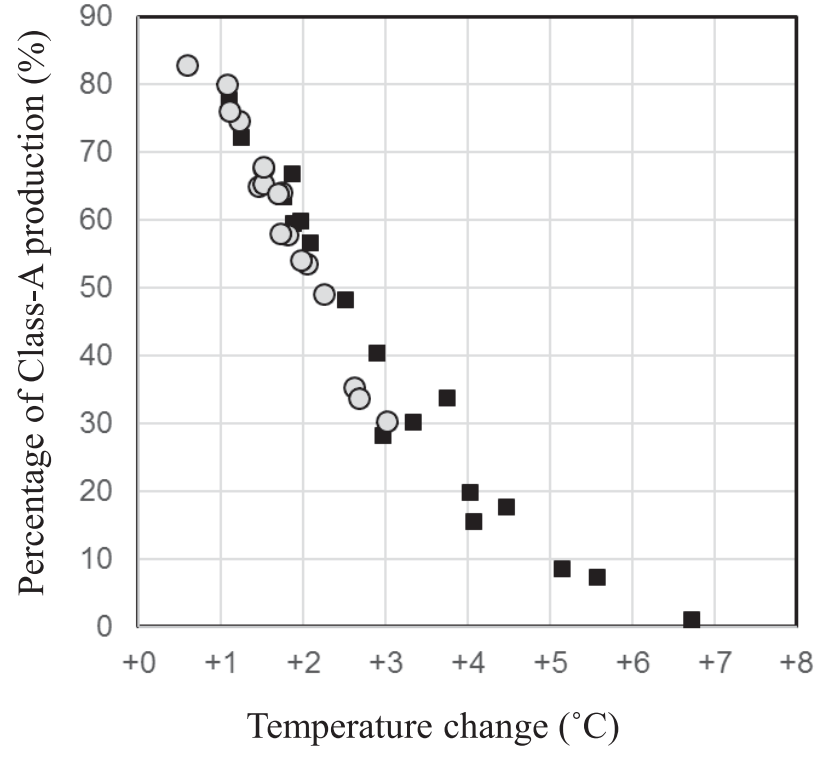

Fig. 4. Relationship between temperature change from the baseline period (1981-2000) and percentage of class A production within the mid period $(2031-2050, \bigcirc)$ and late period (2081-2100,

the temperature increase. In the case of HadGEM2-ES + RCP8.5, the low values covered almost the entire nation, including Hokkaido and the Pacific Ocean side of the Tohoku region, where rice cultivation has historically been restricted by the cool climate.

In addition, to reveal the temporal change in the proportion of each class within total production, we assessed the time series of changes in the total production and the components of each class from 1981 to 2100 averaged for each 20-year interval for the three sample scenarios (Fig. $6 \mathrm{a}-\mathrm{c}$ ). In all cases, the total production levels increased continuously, although a slight decrease appeared in the period of 2081-2100 for BCC-CSM1.1 + RCP2.6 and HadGEM2-ES + RCP8.5. However, the proportion of class C production may increase continuously during the period, especially for HadGEM2-ES + RCP8.5. The differences in estimated total production and class A production among climate change scenarios are shown in Fig. 7. The uncertainties in total production estimates are not large, whereas those of class A production are large.

\subsection{The effect of adaptation by shifting the transplanting date}

We evaluated the effects of two types of adaptation strategies at reducing the negative impact of climate change on rice productivity. Because total rice production was estimated to increase under most climate change scenarios, the adaptation strategy should emphasize the maintenance of quality under increasing temperatures. Therefore, we focus mainly on the effect of applying adaptation 2. However, it is also important to clarify the potential of rice productivity under the expected future climate conditions, considering the possible increase in demand for rice due to dramatic reformation of the social environment and international relations. Here, we briefly introduce the results of adaptation 1 and then describe the results of adaptation 2 .

\subsubsection{Optimal transplanting date for maximum yield (adaptation 1)}

Table 5 lists the 20-year average of total production (expressed as a percentage of the total with no adaptation) and the percentage of each class in the baseline, mid, and late periods, which were based on optimal transplanting date selected by using the adaptation 1 method. The total production level in the baseline period
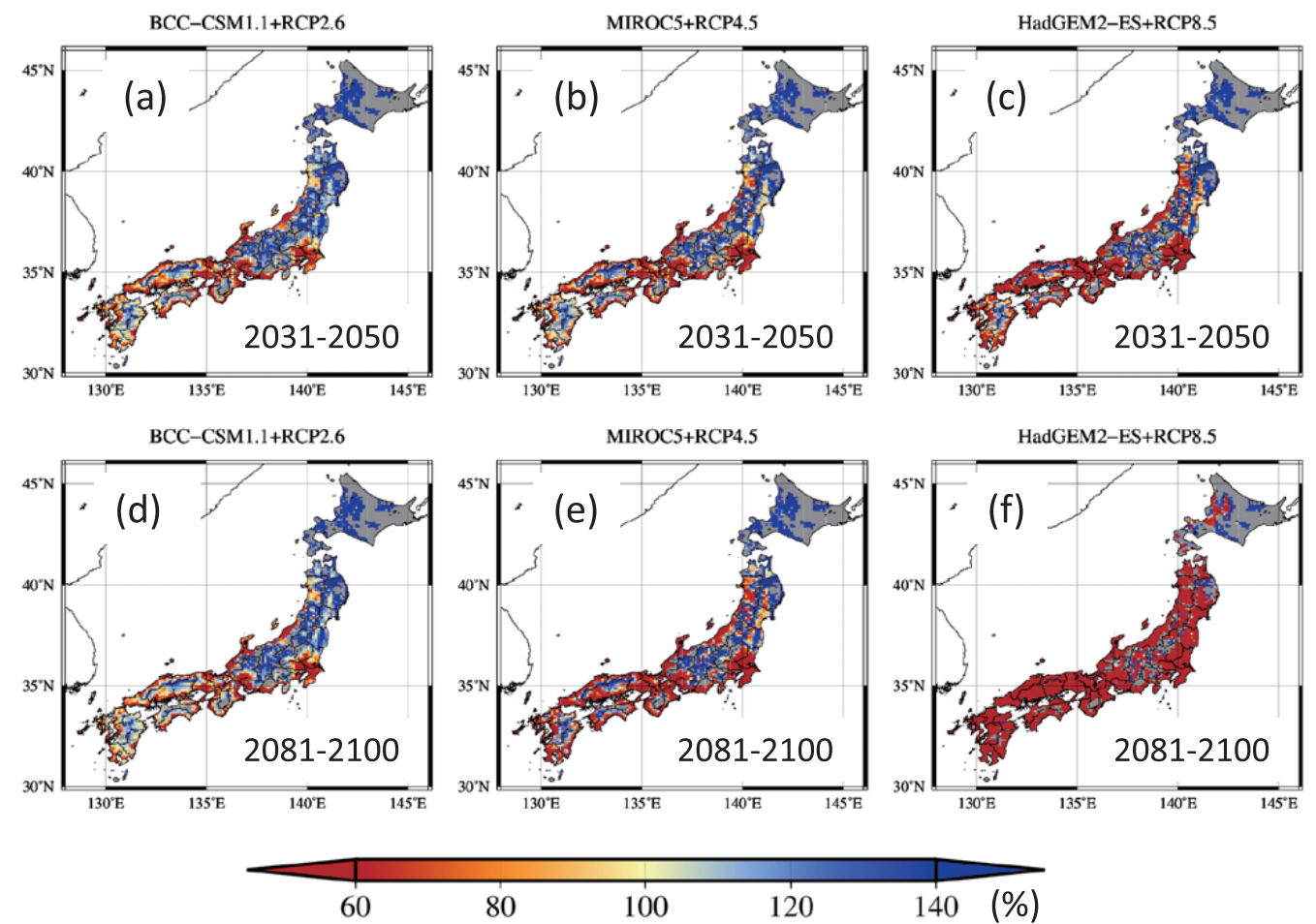

80

100

120

$140(\%)$

Fig. 5. Distribution maps of percentage of 20-year averages of class A yield relative to that in the baseline period (1981-2000). $(\mathrm{a}-\mathrm{c})$ Mid period (2031-2050) and (d-f) late period (2081-2100) calculated using three climate change scenarios (BCCCSM1.1 + RCP2.6, MIROC5 + RCP4.5, and HadGEM2-ES + RCP8.5). 
was estimated to be $113 \%$ in all cases, indicating that rice production could be increased by $13 \%$ even in the baseline period by selecting the optimal transplanting date in each cell. In the mid and late periods, the total production increases ranged from $130.1 \%$ to $142.2 \%$ (average, $135.5 \%$ ) and from $127.1 \%$ to $168.6 \%$ (average, $146.3 \%$ ), respectively. In addition, the differences in the proportion of components of each class showed a similar trend as with no adaptation (Table 4); that is, the percentage of class A
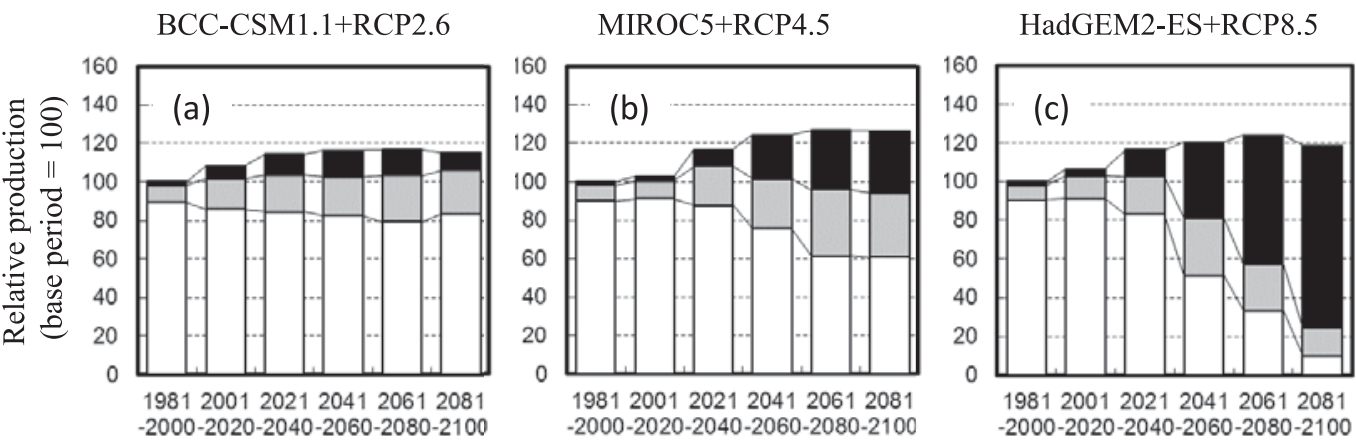

$\square$ ClassA $\square$ ClassB $\square$ ClassC

Fig. 6. Time series of changes in the total rice production and components of each class: (a) BCC-CSM1.1 + RCP2.6, (b) MIROC5 + RCP4.5, (c) HadGEM2-ES + RCP8.5. Production levels are expressed as percentage of that of baseline period (1981-2000).
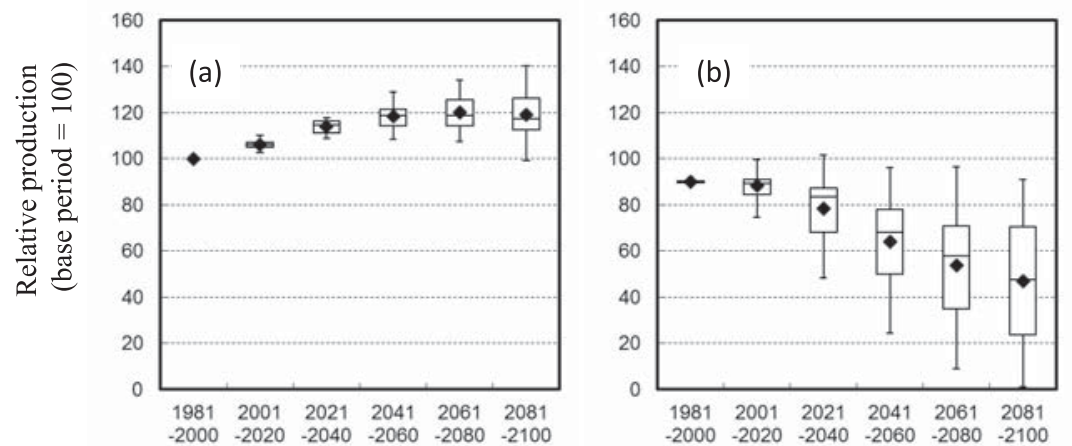

Fig. 7. Time series of change in (a) total production and (b) class A production from all 18 climate change scenarios. Both productions are expressed as a percentage of those of the baseline period (1981-2000). Box plots show average $(\nabla)$; 75th percentile, median, and 25th percentile (upper, middle, and lower lines); and maximum and minimum (whiskers).

Table 5. Relative rice production and percentage of each class based on adaptation 1 for each climate change scenario during the baseline, mid, and late periods.

\begin{tabular}{|c|c|c|c|c|c|c|c|c|c|c|c|c|c|}
\hline \multirow{3}{*}{$\mathrm{RCP}$} & \multirow{3}{*}{$\mathrm{GCM}$} & \multicolumn{4}{|c|}{$1981-2000$} & \multicolumn{4}{|c|}{$2031-2050$} & \multicolumn{4}{|c|}{$2081-2100$} \\
\hline & & \multirow{2}{*}{$\begin{array}{c}\text { Relative } \\
\text { production }{ }^{1)} \\
(\%)\end{array}$} & \multicolumn{3}{|c|}{ Percentage of each class } & \multirow{2}{*}{$\begin{array}{c}\text { Relative } \\
\text { production }{ }^{1)} \\
(\%)\end{array}$} & \multicolumn{3}{|c|}{ Percentage of each class } & \multirow{2}{*}{$\begin{array}{c}\text { Relative } \\
\text { production }{ }^{1)} \\
(\%)\end{array}$} & \multicolumn{3}{|c|}{ Percentage of each class } \\
\hline & & & $\begin{array}{c}\text { Class A } \\
(\%)\end{array}$ & $\begin{array}{c}\text { Class B } \\
(\%)\end{array}$ & $\begin{array}{c}\text { Class C } \\
(\%)\end{array}$ & & $\begin{array}{c}\text { Class A } \\
(\%)\end{array}$ & $\begin{array}{c}\text { Class B } \\
(\%)\end{array}$ & $\begin{array}{c}\text { Class C } \\
(\%)\end{array}$ & & $\begin{array}{c}\text { Class A } \\
(\%)\end{array}$ & $\begin{array}{c}\text { Class B } \\
(\%)\end{array}$ & $\begin{array}{c}\text { Class C } \\
(\%)\end{array}$ \\
\hline \multirow{6}{*}{$\mathrm{RCP} 2.6$} & MIROC5 & 113.0 & 81.7 & 13.2 & 5.1 & 138.1 & 55.8 & 25.0 & 19.2 & 136.5 & 53.8 & 25.5 & 20.7 \\
\hline & MRI-CGCM3 & 113.0 & 81.3 & 14.5 & 4.2 & 130.4 & 70.9 & 21.3 & 7.8 & 132.9 & 64.7 & 22.6 & 12.7 \\
\hline & GFDL-CM3 & 113.3 & 81.1 & 14.9 & 4.0 & 130.1 & 29.7 & 27.8 & 42.5 & 127.1 & 21.7 & 25.5 & 52.9 \\
\hline & HadGEM2-ES & 113.1 & 80.6 & 14.6 & 4.8 & 130.5 & 43.2 & 27.8 & 29.0 & 133.2 & 51.8 & 26.8 & 21.4 \\
\hline & CSIRO-Mk3-6-0 & 113.2 & 82.3 & 13.2 & 4.5 & 132.4 & 53.1 & 26.3 & 20.6 & 130.4 & 46.8 & 24.8 & 28.4 \\
\hline & BCC-CSM1.1 & 113.3 & 80.5 & 15.0 & 4.5 & 132.8 & 64.1 & 20.0 & 15.9 & 131.1 & 61.5 & 23.2 & 15.3 \\
\hline \multirow{6}{*}{$\mathrm{RCP} 4.5$} & MIROC5 & 113.3 & 81.7 & 13.1 & 5.2 & 139.8 & 54.4 & 23.6 & 22.0 & 150.6 & 41.6 & 26.9 & 31.5 \\
\hline & MRI-CGCM3 & 112.9 & 81.1 & 14.6 & 4.3 & 135.5 & 68.9 & 21.9 & 9.2 & 148.5 & 56.9 & 26.4 & 16.6 \\
\hline & GFDL-CM3 & 113.3 & 81.3 & 14.7 & 4.0 & 131.4 & 29.0 & 27.1 & 44.0 & 141.4 & 18.0 & 22.8 & 59.2 \\
\hline & HadGEM2-ES & 113.2 & 80.6 & 14.5 & 4.9 & 135.1 & 46.2 & 29.5 & 24.2 & 144.0 & 29.1 & 29.5 & 41.4 \\
\hline & CSIRO-Mk3-6-0 & 113.4 & 82.4 & 13.2 & 4.4 & 135.6 & 54.5 & 23.3 & 22.3 & 143.0 & 33.2 & 25.9 & 40.8 \\
\hline & BCC-CSM1.1 & 113.5 & 80.5 & 15.0 & 4.5 & 137.0 & 55.4 & 23.8 & 20.8 & 145.5 & 47.4 & 25.9 & 26.7 \\
\hline \multirow{6}{*}{ RCP8.5 } & MIROC5 & 1132 & 81.5 & 13.4 & 5 . & 142.2 & 47.2 & 26. & 26.5 & 164.9 & 21. & 26.6 & 52.3 \\
\hline & MRI-CGCM3 & 113.0 & 81.2 & 14.6 & 4.2 & 140.9 & 65.2 & 22.4 & 12.4 & 168.6 & 32.3 & 27.4 & 40.4 \\
\hline & GFDL-CM3 & 113.4 & 81.2 & 15.0 & 3.8 & 133.0 & 28.2 & 27.6 & 44.2 & 154.0 & 13.5 & 22.7 & 63.8 \\
\hline & HadGEM2-ES & 113.1 & 80.5 & 14.7 & 4.8 & 138.1 & 40.7 & 28.8 & 30.5 & 160.7 & 21.2 & 23.7 & 55.1 \\
\hline & CSIRO-Mk3-6-0 & 113.4 & 82.3 & 13.4 & 1. & 138.8 & 49.0 & 24.1 & 26.9 & 161.4 & 12.6 & 21.3 & 66.0 \\
\hline & BCC-CSM1.1 & 113.5 & 80.5 & 15.0 & 4.5 & 137.8 & 51.7 & 24.7 & 23.6 & 160.7 & 21.9 & 24.0 & 54.1 \\
\hline
\end{tabular}

\footnotetext{
1) Percentage of the nationwide total rice production relative to that of baseline period (1981-2000) on the basis of standard transplanting date (no adaptation).
} 
production decreased along with the temperature increase.

Figures 8 and 9 show the geographic distributions of the percentage of total yield and of class A yield relative to the total yield in the baseline period, as based on the optimal transplanting date selected by the adaptation 1 method in the mid and late periods for the sample scenarios (see Fig. S5(mid-period)
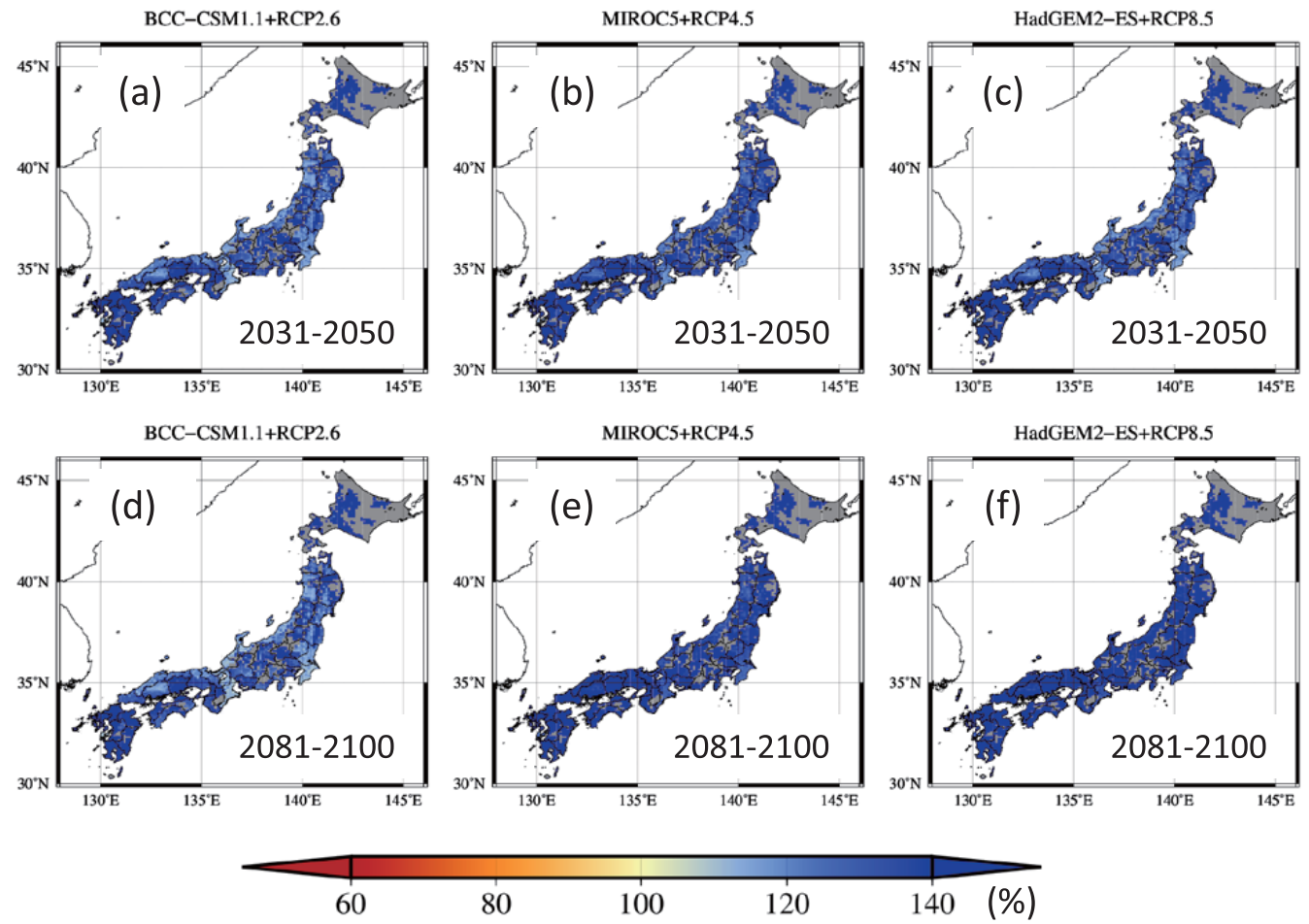

80

100

120

$140(\%)$

Fig. 8. Distribution maps of percentage of 20-year averages of total yield based on adaptation 1 relative to that in the baseline period (1981-2000) with no adaptation. (a-c) Mid period (2031-2050) and (d-f) late period (2081-2100) calculated using three climate change scenarios (BCC-CSM1.1 + RCP2.6, MIROC5 + RCP4.5, and HadGEM2-ES + RCP8.5).
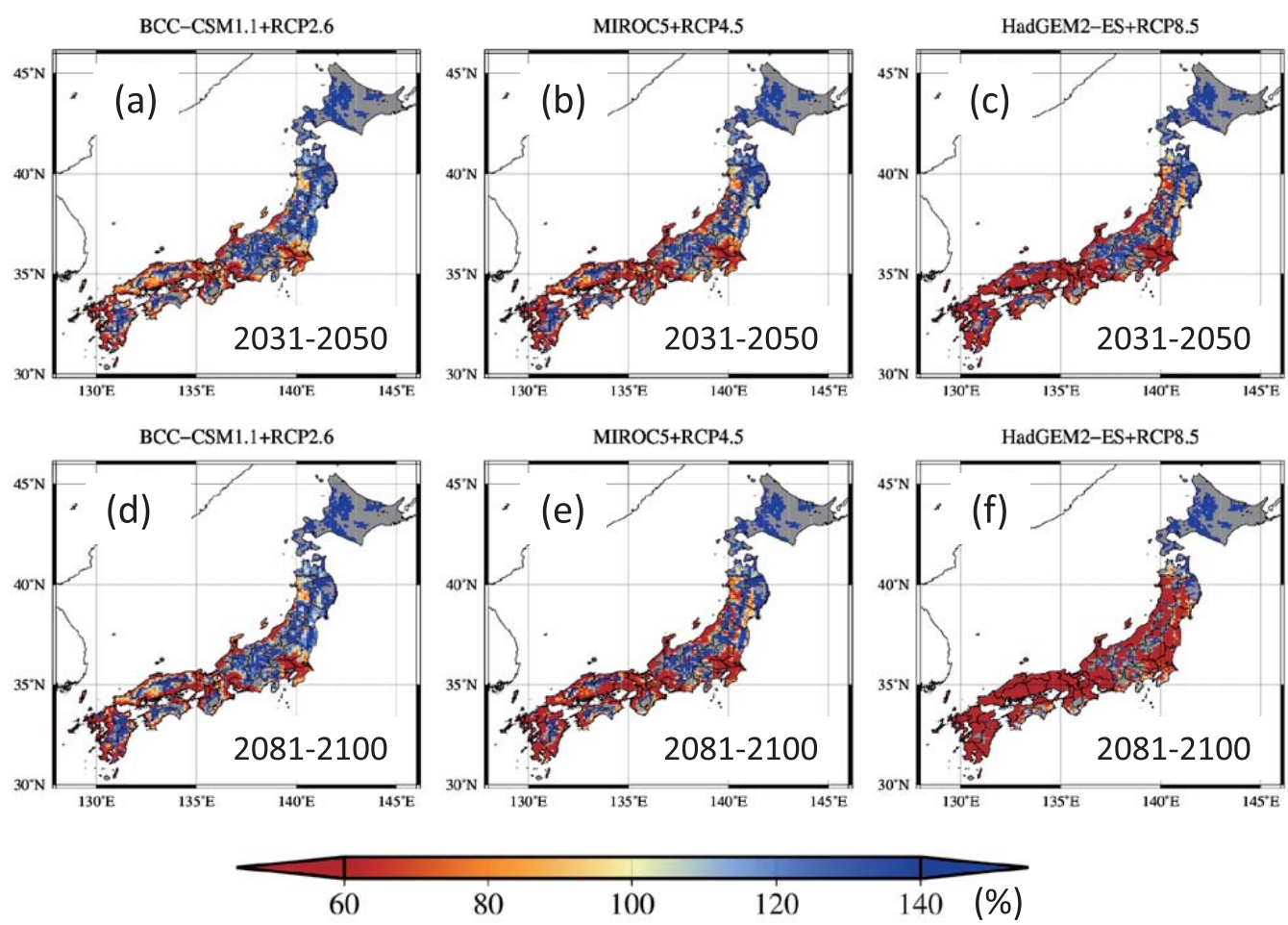

80

100

120

$140(\%)$

Fig. 9. Distribution maps of percentage of 20-year averages of class A yield based on adaptation 1 relative to that in the baseline period (1981-2000) with no adaptation. (a-c) Mid period (2031-2050) and (d-f) late period (2081-2100) calculated using three climate change scenarios (BCC-CSM1.1 + RCP2.6, MIROC5 + RCP4.5, and HadGEM2-ES + RCP8.5). 
and S6(late-period) for all results corresponding with Fig. 8; Fig. S7(mid-period) and S8(late-period) for all results corresponding with Fig. 9). The total yield was estimated to increase across the nation (Fig. 8), including in the areas where a large decrease was predicted with no adaptation (Fig. 3). The class A yield was estimated to be low in the plains and inland basins, except in northern and northeastern Japan (Fig. 9), as in the case with no adaptation (Fig. 5). The temporal changes in the total production and the component of each class for the sample scenarios are shown in Fig. 10a-c. The changes in the components were similar to those in no adaptation (Fig. 6a-c), but the total production level increased largely compared to those in no adaptation. These results indicate that rice yield can be increased anywhere and the total production can be increased largely under the projected climate conditions unless quality is regarded as a crucial factor.

In terms of the optimal transplanting date to obtain the highest yield, Fig. 11 shows the shift in date selected on the basis of the adaptation 1 method compared with the standard one (see Fig. S9(mid-period) and S10(late-period) for all results corresponding with Fig. 11). The transplanting dates shift earlier from the southern Tohoku region southward. In contrast, there was no significant change in the northern Tohoku and Hokkaido regions, which implies that the current standard transplanting date may be optimal even under the projected future climate conditions in this area.

\subsubsection{Optimal transplanting date for both yield and quality (adaptation 2)}

Table 6 lists the relative rice production and percentage of each production class based on adaptation 2 for each climate change scenario during the three periods. The total production in the baseline period was estimated to be approximately $104 \%$ in all cases, whereas it changed from $94.5 \%$ to $119.7 \%$ (average, $107 \%$ ) in the mid period and from $92.1 \%$ to $120.5 \%$ (average, $106.3 \%)$ in the late period. In addition, there was no remarkable change in the proportion of components of each class among the climate change scenarios. The percentage of class A production varied from $93.5 \%$ to $97.7 \%$ in the mid period and from $71.1 \%$ to $98.0 \%$ in the late period, both of which were significantly higher than those with no adaptation (Table 4) and adaptation 1 (Table 5). However, the percentage of class $\mathrm{C}$ production was less than $10 \%$, even when large temperature increase were projected (e.g., HadGEM2-ES and GFDL-CM3 with RCP8.5).
Figures 12 and 13 show the geographic distributions of the percentage of total yield and of class A yield relative to total yield in the baseline period, both of which were based on the optimal transplanting date selected by the adaptation 2 method in the mid and late period for the sample scenarios (see Fig. S11(mid-period) and S12(late-period) for all results corresponding with Fig. 12; Fig. S13(mid-period) and S14(late-period) for all results corresponding with Fig. 13). With regard to total yield (Fig. 12), although the distribution patterns of adaptation 2 are generally similar to those with no adaptation (Fig. 3), the areas where the yield tended to decrease were widely expanded in the adaptation 2 cases. In addition, the large decreasing area found with no adaptation in 2081-2100 (Fig. 3f) was not apparent in the adaptation 2 case, suggesting that the large decrease in yield due to spikelet sterility caused by heat stress during the early ripening period can be avoided by shifting the transplanting date.

With regard to the distributions of class A yield based on adaptation 2 (Fig. 13), in all cases the decreasing areas were estimated to be significantly smaller than those based on no adaptation (Fig. 5). In addition, the spatial distribution patterns of class A yield and of total yield were similar to each other. The temporal changes in the total production and the components of each class for the sample scenarios are shown in Fig. 14a-c. There seems to be no remarkable temporal changes in both the total production level and the proportion of class A composing the most of production throughout the whole period. These results indicate that most of the total yield was composed of class A at the national scale, and thus shifting the transplanting date appropriately may avoid the negative impact of projected temperature increase on both quantity and quality of rice. However, a remarkable large decline in class A yield was apparent in some areas, especially on the Kanto Plain and in the Tokai and Hokuriku regions. In these cases, it seems to be difficult to avoid the impact of temperature increase only by shifting the transplanting date.

Figure 15 shows the shift in the selected optimal transplanting date based on the adaptation 2 method compared with the standard one (see Fig. S15(mid-period) and S16(late-period) for all results corresponding with Fig. 15). In general, the optimal transplanting date was later than that in the case of adaptation 1 (Fig. 11), indicating that the heading date and ripening period needed to shift to after the peak of high temperature in midsummer. Later
BCC-CSM1.1+RCP2.6

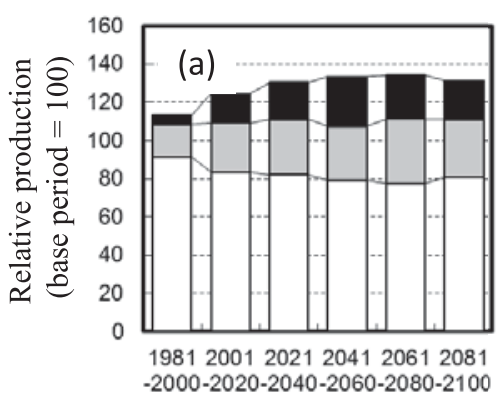

MIROC5+RCP4.5

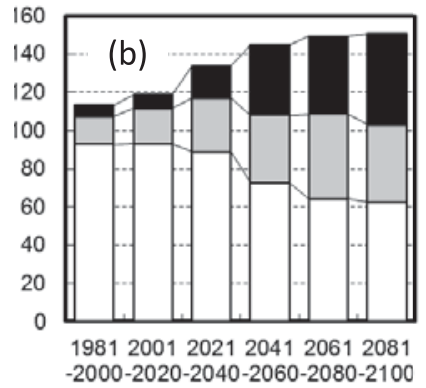

HadGEM2-ES+RCP8 5

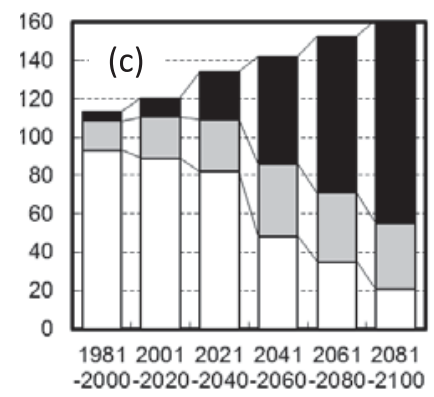

\section{$\square$ ClassA $\square$ ClassB ClassC}

Fig. 10. Time series of changes in the total rice production and components of each class based on adaptation 1: (a) BCC-CSM1.1 + RCP2.6, (b) MIROC5 + RCP4.5, (c) HadGEM2-ES + RCP8.5. Production levels are expressed as percentage of that of baseline period (1981-2000). 

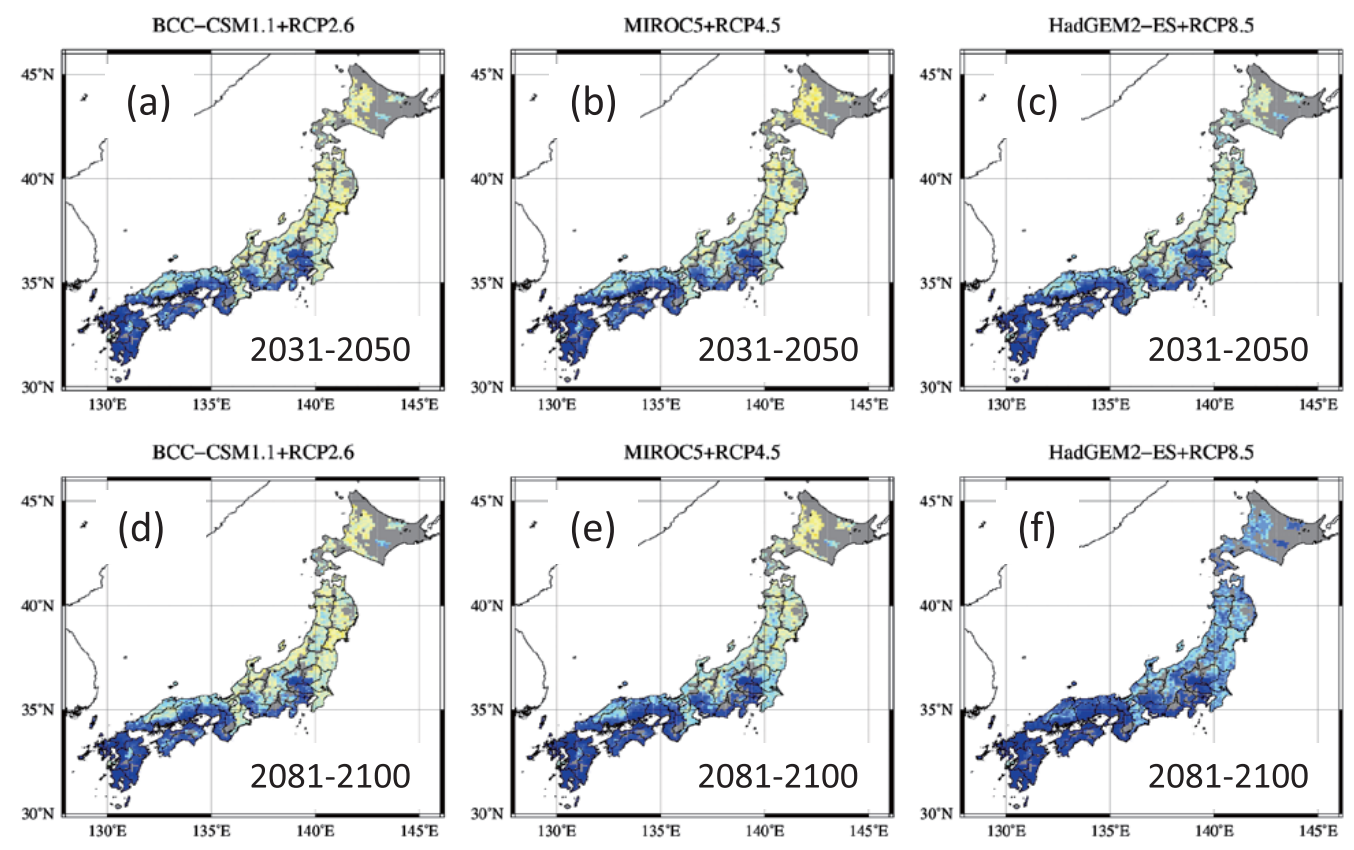

$$
\begin{array}{llllllll}
-60 & -40 & -20 & 0 & 20 & 40 & 60 & \text { (days) }
\end{array}
$$

Fig. 11. Distribution maps of the number of days by which transplanting date is shifted based on the method of adaptation 1. (a-c) Mid period (2031-2050) and (d-f) late period (2081-2100) calculated using three climate change scenarios (BCC-CSM1.1 + RCP2.6, MIROC5 + RCP4.5, and HadGEM2-ES + RCP8.5, respectively). Negative values indicate that the optimal transplanting date shifts earlier, and positive values indicate later.

Table 6. Relative rice production and percentage of each class based on adaptation 2 for each climate change scenario during the baseline, mid, and late periods.

\begin{tabular}{|c|c|c|c|c|c|c|c|c|c|c|c|c|c|}
\hline \multirow{3}{*}{$\mathrm{RCP}$} & \multirow{3}{*}{ GCM } & \multicolumn{4}{|c|}{$1981-2000$} & \multicolumn{4}{|c|}{$2031-2050$} & \multicolumn{4}{|c|}{$2081-2100$} \\
\hline & & \multirow{2}{*}{$\begin{array}{c}\text { Relative } \\
\text { production }^{1)} \\
(\%)\end{array}$} & \multicolumn{3}{|c|}{ Percentage of each class } & \multirow{2}{*}{$\begin{array}{c}\text { Relative } \\
\text { production }{ }^{1)} \\
(\%)\end{array}$} & \multicolumn{3}{|c|}{ Percentage of each class } & \multirow{2}{*}{$\begin{array}{c}\text { Relative } \\
\text { production }^{1)} \\
(\%)\end{array}$} & \multicolumn{3}{|c|}{ Percentage of each class } \\
\hline & & & $\begin{array}{c}\text { Class A } \\
(\%)\end{array}$ & $\begin{array}{c}\text { Class B } \\
(\%)\end{array}$ & $\begin{array}{c}\text { Class C } \\
(\%)\end{array}$ & & $\begin{array}{c}\text { Class A } \\
(\%)\end{array}$ & $\begin{array}{c}\text { Class B } \\
(\%)\end{array}$ & $\begin{array}{c}\text { Class C } \\
(\%)\end{array}$ & & $\begin{array}{c}\text { Class A } \\
(\%)\end{array}$ & $\begin{array}{c}\text { Class B } \\
(\%)\end{array}$ & $\begin{array}{c}\text { Class C } \\
(\%)\end{array}$ \\
\hline \multirow{6}{*}{$\mathrm{RCP} 2.6$} & MIROC5 & 103.3 & 96.4 & 3.0 & 0.5 & 111.0 & 93.5 & 5.0 & 1.6 & 106.9 & 94.9 & 3.6 & 1.4 \\
\hline & MRI-CGCM3 & 103.7 & 97.1 & 2.7 & 0.2 & 114.2 & 97.7 & 2.2 & 0.1 & 113.6 & 98.0 & 1.9 & 0.1 \\
\hline & GFDL-CM3 & 104.3 & 97.0 & 2.8 & 0.2 & 94.5 & 96.1 & 3.4 & 0.5 & 92.1 & 95.3 & 4.0 & 0.7 \\
\hline & HadGEM2-ES & 104.0 & 95.4 & 3.5 & 1.1 & 99.3 & 95.3 & 4.1 & 0.6 & 105.8 & 95.4 & 3.7 & 0.9 \\
\hline & CSIRO-Mk3-6-0 & 104.6 & 95.8 & 3.5 & 0.7 & 105.6 & 96.5 & 3.0 & 0.5 & 102.8 & 97.3 & 2.4 & 0.3 \\
\hline & BCC-CSM1.1 & 103.9 & 96.8 & 2.8 & 0.4 & 109.2 & 96.1 & 3.3 & 0.6 & 109.0 & 96.4 & 3.2 & 0.4 \\
\hline \multirow{6}{*}{ RCP4.5 } & MIROC5 & 103.7 & 96.1 & 3.2 & 0.7 & 109.4 & 94.6 & 4.0 & 1.4 & 109.2 & 94.3 & 4.2 & 1.5 \\
\hline & MRI-CGCM3 & 103.3 & 97.2 & 2.6 & 0.2 & 117.0 & 95.7 & 3.8 & 0.6 & 120.5 & 95.9 & 3.6 & 0.5 \\
\hline & GFDL-CM3 & 104.3 & 96.8 & 2.9 & 0.3 & 96.0 & 94.8 & 4.3 & 0.9 & 94.5 & 87.6 & 8.4 & 4.0 \\
\hline & HadGEM2-ES & 104.1 & 95.3 & 3.5 & 1.2 & 105.3 & 96.3 & 3.3 & 0.4 & 104.2 & 92.3 & 5.8 & 1.9 \\
\hline & CSIRO-Mk3-6-0 & 104.5 & 96.0 & 3.3 & 0.7 & 106.9 & 96.4 & 2.9 & 0.7 & 105.5 & 96.8 & 2.7 & 0.5 \\
\hline & BCC-CSM1.1 & 104.1 & 96.6 & 2.9 & 0.5 & 109.6 & 96.7 & 2.8 & 0.5 & 110.9 & 95.5 & 4.0 & 0.5 \\
\hline \multirow{6}{*}{ RCP8.5 } & MIROC5 & 103.3 & 96.5 & 2.9 & 0.6 & 109.3 & 94.9 & 4.2 & 0.9 & 106.0 & 86.3 & 9.1 & 4.6 \\
\hline & MRI-CGCM3 & 103.5 & 97.2 & 2.6 & 0.2 & 119.7 & 94.6 & 4.0 & 1.4 & 113.6 & 91.5 & 7.0 & 1.5 \\
\hline & GFDL-CM3 & 104.3 & 97.1 & 2.8 & 0.2 & 97.8 & 94.2 & 3.9 & 1.9 & 95.6 & 71.1 & 20.2 & 8.7 \\
\hline & HadGEM2-ES & 104.3 & 95.1 & 3.7 & 1.2 & 104.1 & 96.8 & 2.9 & 0.3 & 107.9 & 79.1 & 14.4 & 6.5 \\
\hline & CSIRO-Mk3-6-0 & 104.6 & 96.0 & 3.4 & 1.9 & 107.4 & 95.1 & 3.3 & 1.6 & 107.2 & 89.7 & 7.6 & 2.6 \\
\hline & BCC-CSM1.1 & 104.1 & 96.6 & 2.9 & 0.5 & 108.9 & 97.2 & 2.5 & 0.3 & 108.1 & 89.5 & 7.7 & 2.8 \\
\hline
\end{tabular}

${ }^{1)}$ Percentage of the nationwide total rice production relative to that of baseline period (1981-2000) on the basis of standard transplanting date (no adaptation).

transplanting is generally an adaptive countermeasure and has been implemented widely in Japan in recent years (Morita et al., 2016). However, later transplanting leads to a disadvantage in yield formation because the ripening period shifts to autumn when solar radiation energy is insufficient for adequate grain filling (Horie et al., 1995b). The optimal transplanting date was earlier in some areas under the scenario predicting a large temperature increase. In this case, the ripening period can be completed before the peak of high temperature in midsummer, and high yield can be expected because the major growing period corresponds with the period of high solar radiation (from late spring to early summer). 


\section{Conclusion}

In this study, the $\mathrm{H} / \mathrm{H}$ rice growth model was validated using observed statistical data and the performance was confirmed to be sufficient to use for the purpose of this study. Our findings have two major implications for Japanese rice farmers. First, based on the condition of current transplanting date, nationwide total rice production was estimated to increase slightly in most
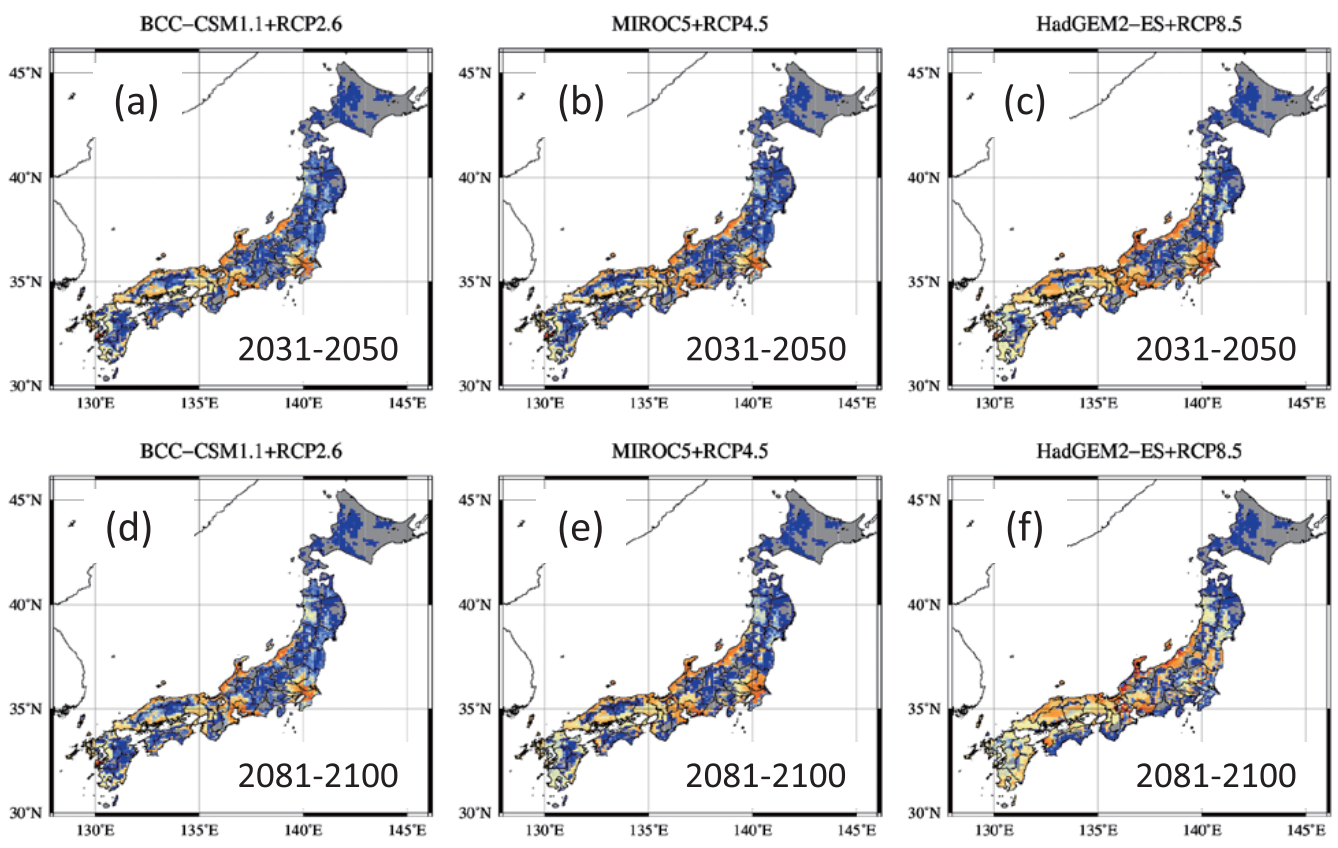

60

80

100

120

$140(\%)$

Fig. 12. Distribution maps of percentage of 20 -year averages of total yield based on adaptation 2 relative to that in the baseline period (1981-2000) with no adaptation. (a-c) Mid period (2031-2050) and (d-f) late period (2081-2100) calculated using three climate change scenarios (BCC-CSM1.1 + RCP2.6, MIROC5 + RCP4.5, and HadGEM2-ES + RCP8.5).
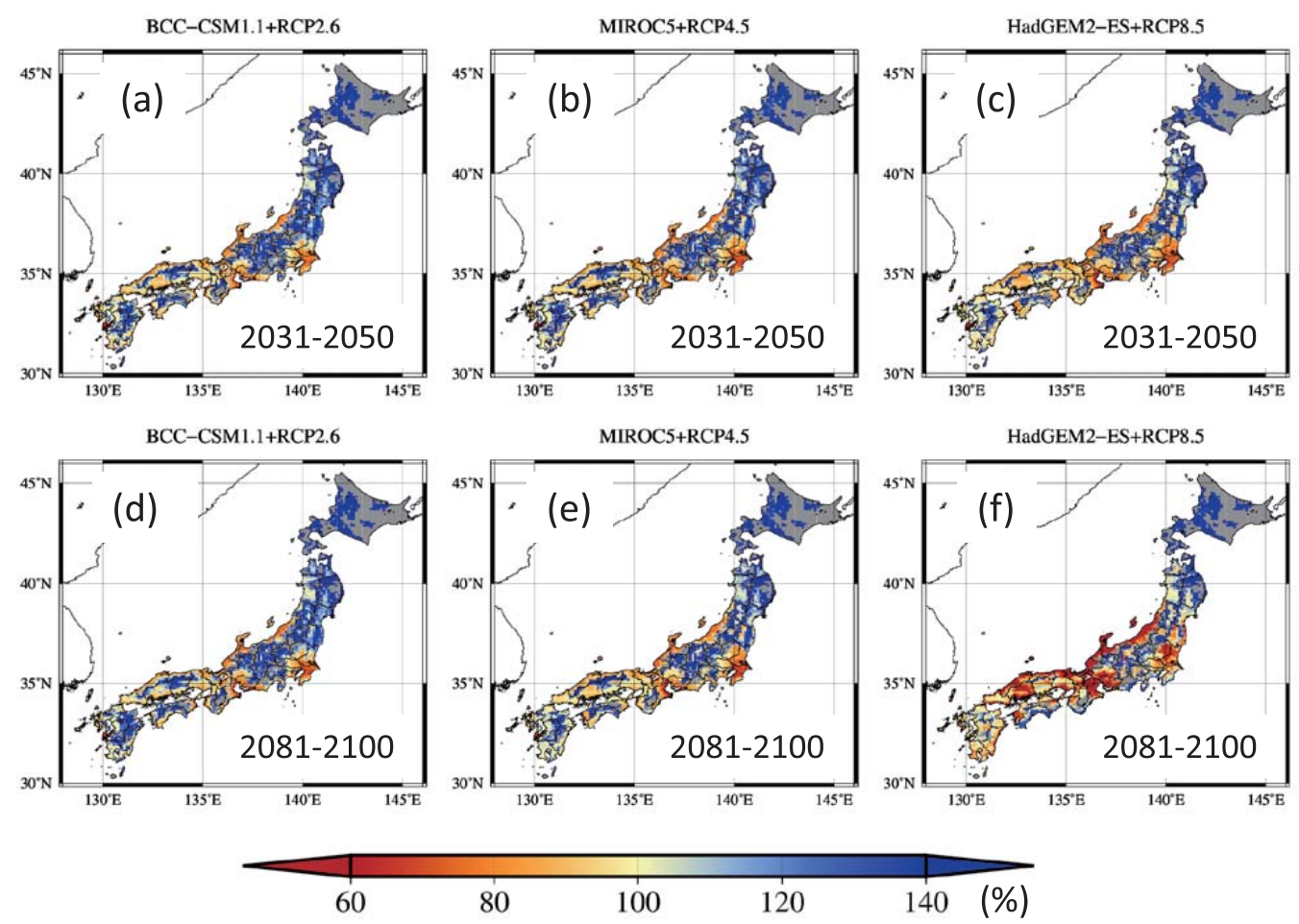

$$
80
$$

100

120

$140 \quad(\%)$

Fig. 13. Distribution maps of percentage of 20-year averages of class A yield based on adaptation 2 relative to that in the baseline period (1981-2000) with no adaptation. (a-c) Mid period (2031-2050) and (d-f) late period (2081-2100) calculated using three climate change scenarios (BCC-CSM1.1 + RCP2.6, MIROC5 + RCP4.5, and HadGEM2-ES + RCP8.5). 

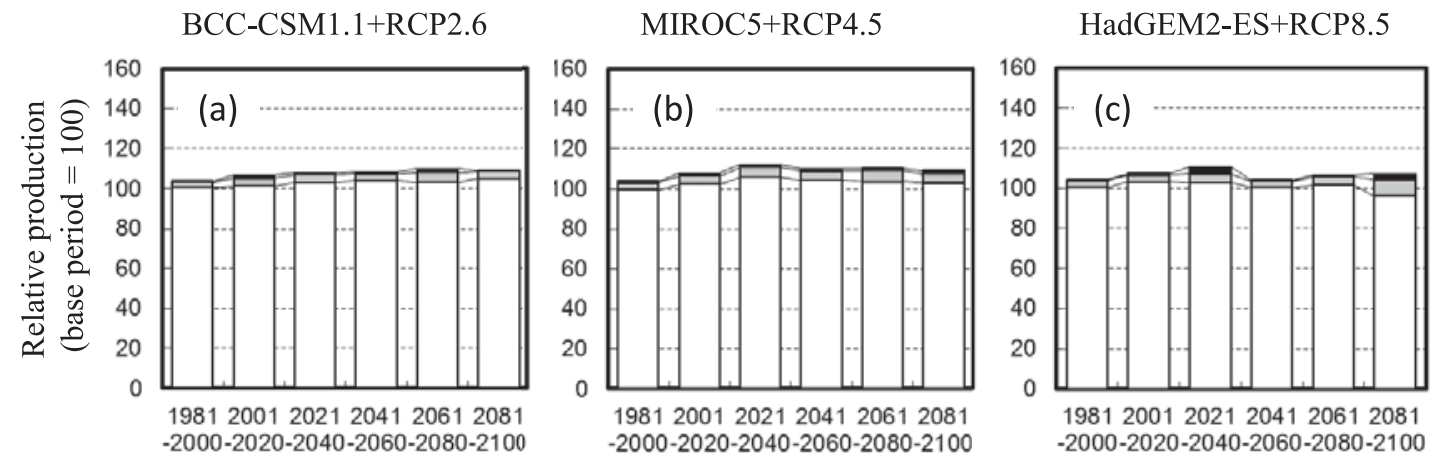

\section{$\square$ ClassA $\square$ ClassB $\because$ ClassC}

Fig. 14. Time series of changes in the total rice production and components of each class based on adaptation 2: (a) BCCCSM1.1 + RCP2.6, (b) MIROC5 + RCP4.5, (c) HadGEM2-ES + RCP8.5. Production levels are expressed as percentage of that of baseline period (1981-2000).

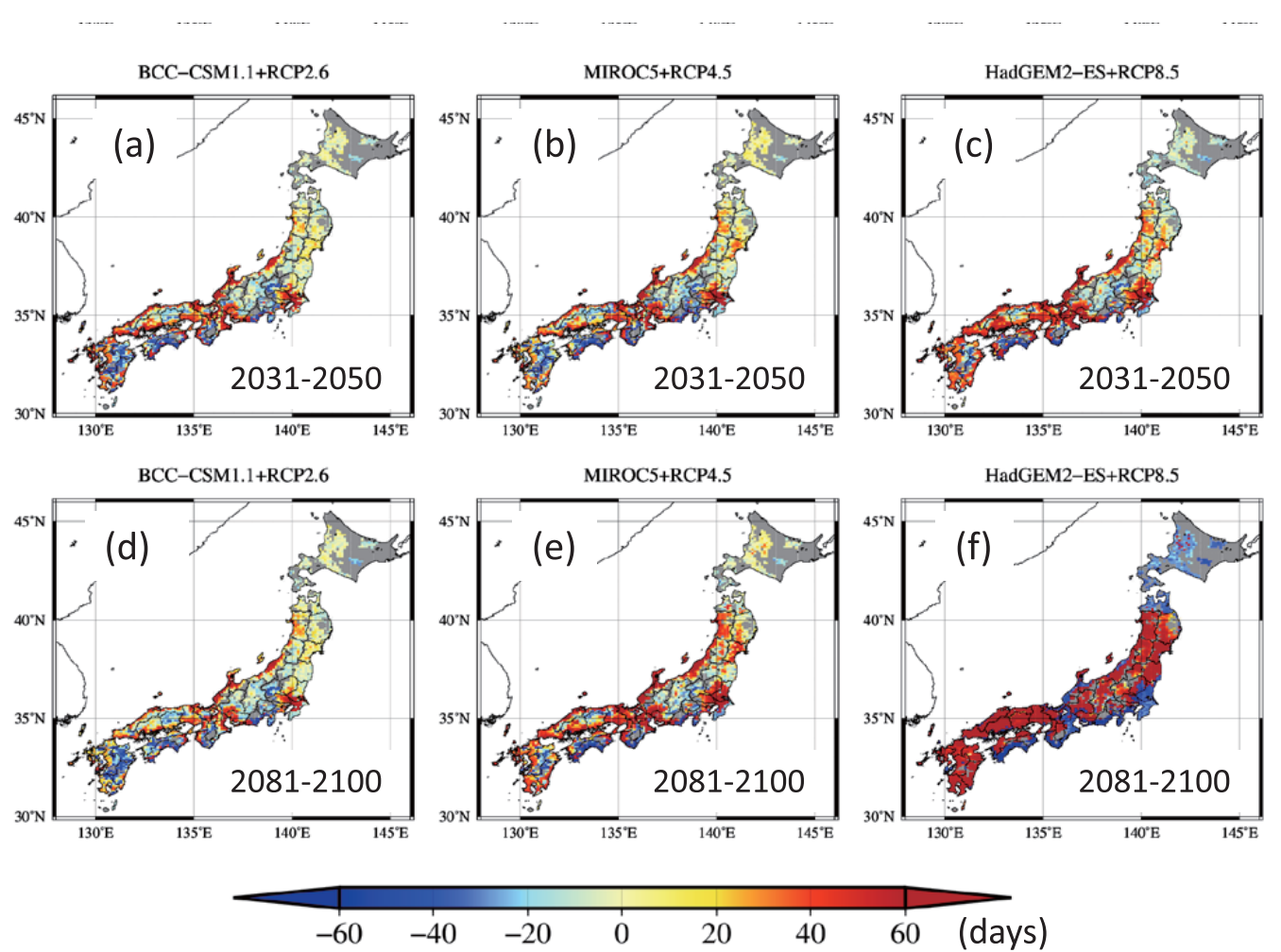

Fig. 15. Distribution maps of the number of days by which transplanting date is shifted based on the method of adaptation 2. (a-c) Mid period (2031-2050) and (d-f) late period (2081-2100) calculated using three climate change scenarios (BCC-CSM1.1 + RCP2.6, MIROC5 + RCP4.5, and HadGEM2-ES + RCP8.5). Negative values indicate that the optimal transplanting date shifts earlier, and positive values indicate later.

climate change scenarios, but the proportion of production with quality degradation risk may increase along with the temperature increase. Second, it may be possible to avoid the increase in quality degradation risk while maintaining total production by selecting optimum transplanting dates in consideration of both yield and quality. However, a large decrease in yield was predicted in some areas, suggesting that the current rice producing region would be separated into distinctly suitable and unsuitable areas with the temperature increase.

In this study, only shifting the transplanting date was considered as an adaptive measure. Indeed, this measure has been widely implemented in Japan recently and has achieved some good results in preventing the reduction of rice quality by high temperatures (MAFF, 2006a). However, our findings suggest that the effectiveness will be limited in the case of a large increase in temperature. Many other adaption options may be available to reduce negative impacts of climate change on rice production, including cultivars having heat tolerance and/or different phenology characteristics for heat avoidance, and appropriate management in water and fertilization (e.g., Morita et al., 2016). In particular, the appropriate nitrogen application can reduce the occurrence of rice heat damage remarkably (Morita et al., 2016). Additionally, some important factors are not taken into account in this study: changes in available water resources and 
in the distribution of paddy field, extreme weather phenomenon including typhoon, and expansion of new disease or insect; all of which should be noted when interpreting the results derived from our investigation. To introduce a workable adaptation measure, it is important to select the adaptation option that is most suitable for the specific condition or to combine several adaptation options appropriately. Therefore, we plan to conduct further experiments with respect to the effectiveness of various adaptation options under a wide range of climatic conditions.

\section{Supplemental information}

Supplemental information for this paper is available at http://doi.org/10.2480/agrmet.D-16-00024

\section{Acknowledgments}

The authors gratefully acknowledge the Institute of Crop Science, National Agriculture and Food Research Organization, and the Production, Marketing and Consumption Statistics Division, Minister's Secretariat, MAFF, for providing the CSCS datasets. This study was supported as part of research projects funded by the Ministry of Education, Culture, Sports, Science and Technology ("Social Implementation Program on Climate Change Adaptation Technology"), the Ministry of the Environment ("Comprehensive Research on Climate Change Impact Assessment and Adaptation Policies", S8), and the Ministry of Agriculture, Forestry and Fisheries ("Development of Technologies for Mitigation and Adaptation to Climate Change in Agriculture, Forestry and Fisheries"). We are grateful to Dr. S. Sawano of the Forestry and Forest Products Research Institute for assistance to calculate yearly nitrogen fertilizer amount.

\section{References}

Collatz GT, Ball JT, Grivet C, Berry JA, 1991: Physiological and environmental regulation of stomatal conductance, photosynthesis and transpiration: a model that includes a laminar boundary layer. Agricultural and Forest Meteorology 54, 107-136.

Farquhar GD, von Caemmerer S, Berry JA, 1980: A biochemical model of photosynthesis $\mathrm{CO}_{2}$ assimilation in leaves of $\mathrm{C} 3$ species. Planta 149(1), 78-90.

Fukui S, Ishigooka Y, Kuwagata T, Hasegawa T, 2015: A methodology for estimating phenological parameters of rice cultivars utilizing data from common variety trials. Journal of Agricultural Meteorology 71(2), 77-89.

Fukui S, Ishigooka Y, Kuwagata T, Kondo M, Hasegawa T, 2017: Taking account of water temperature effects on phenology improves the estimation of rice heading dates: Evidence from 758 field observations across Japan. Journal of Agricultural Meteorology, (in press).

Hasegawa T, Horie T, 1997: Modelling the effect of nitrogen on rice growth and development. In Applications of Systems Approaches at the Field Level. (ed. by Kropff MJ, Teng PS, Aggarwal PK, Bouma J, Bouman BAM, Jones JW, van Laar HH). Kluwer, Dordrecht, pp. 243-257.

Hasegawa T, Sakai H, Tokida T, Usui Y, Yoshimoto M, Fukuoka M, Nakamura H, Shimono H, Okada M, Hatfield JL, Fleisher D, 2016: Rice free-air carbon dioxide enrichment studies to improve assessment of climate change effects on rice agriculture. In Improving Modeling Tools to Assess Climate Change Effects on Crop Response (ed. by Hatfield JL, Fleisher
D). American Society of Agronomy, Madison, WI USA. Doi:10.2134/advagricsystmodel7.2014.0015.

Hayashi Y, Ishigooka Y, Yokozawa H, Toritani H, Goto S, 2001: Impacts of global warming on potential characteristics of rice cultivation in Japan. Global Environmental Research 6, 141148 (in Japanese).

Horie T, Nakagawa H, 1990: Modelling and prediction of development process in rice. I. Structure and method of parameter estimation of a model for simulating development process toward heading. Japanese Journal of Crop Science 59(4), 687695 (in Japanese with English abstract).

Horie T, Nakagawa H, Centeno HGS, Kropff M, 1995a: The rice crop simulation model SIMRIW and its testing. In Modeling the Impact of Climate Change on Rice in Asia. (ed. by Matthews RB, Kropff MJ, Bachelet D, van Laar HH). CAB International, Oxon, pp.51-66.

Horie T, Nakagawa H, Ohnishi M, Nakano J, 1995b: Rice production in Japan under current and future climates. In Modeling the Impact of Climate Change on Rice in Asia. (ed. by Matthews RB, Kropff MJ, Bachelet D, van Laar HH). CAB International, Oxon, pp.143-164.

Iizumi T, Hori ME, Yokozawa M, Nakagawa H, Hayashi Y, Kimura F, 2006: Impact of global warming on rice production in Japan based on five coupled atmosphere-ocean GCMs. SOLA 2, 156-159.

Iizumi T, Yokozawa M, Nishimori M, 2009: Parameter estimation and uncertainty analysis of a large-scale crop model for paddy rice: application of a Bayesian approach. Agricultural and Forest Meteorology 149, 333-348.

Iizumi T, Nishimori M, Ishigooka Y, Yokozawa M, 2010: Introduction to climate change scenario derived by statistical downscaling. Journal of Agricultural Meteorology 66(2), 131143 (in Japanese with English abstract).

Iizumi T, Yokozawa M, Nishimori M, 2011: Probabilistic evaluation of climate change impacts on paddy rice productivity in Japan. Climatic Change 107, 391-415.

Intergovernmental Panel on Climate Change (IPCC), 2014: Climate Change 2014: Impacts, Adaptation, and Vulnerability. Part A: Global and Sectoral Aspects. Contribution of Working Group II to the Fifth Assessment Report of the Intergovernmental Panel on Climate Change (ed. by Field CB, Barros VR, Dokken DJ, Mach KJ, Mastrandrea MD, Bilir TE, Chatterjee M, Ebi KL, Estrada YO, Genova RC, Girma B, Kissel ES, Levy AN, MacCracken S, Mastrandrea PR, White LL). Cambridge University Press, Cambridge and New York, pp.1132.

Ishigooka Y, Kuwagata T, Nishimori M, Hasegawa T, Ohno H, 2011: Spatial characterization of recent hot summers in Japan with agro-climatic indices related to rice production. Journal of Agricultural Meteorology 67(4), 209-224.

Katayanagi N, Fumoto T, Hayano M, Takata Y, Kuwagata T, Shirato Y, Sawano S, Kajiura M, Sudo S, Ishigooka Y, Yagi K, 2016: Development of a method for estimating total $\mathrm{CH}_{4}$ emission from rice paddies in Japan using the DNDC-Rice model. Science of The Total Environment 547, 429-440.

Kondo J, Nakoamura T, Yamazaki T, 1991: Estimation of solar radiation and downward atmospheric radiation. Tenki 38, 4148 (in Japanese).

Kuwagata T, Hamasaki T, Watanabe T, 2008: Modeling water temperature in a rice paddy for agro-environmental research. Agricultural and Forest Meteorology 148, 1754-1766.

Li H, Sheffield J, Wood EF, 2010: Bias correction of monthly precipitation and temperature fields from Intergovernmental 
Panel on Climate Change AR4 models using equidistant quantile matching. Journal of Geophysical Research 115, D10101.

Li T, Hasegawa T, Yin X, Zhu Y, Boote K, Adam M, Bregaglio S, Buis S, Confalonieri R, Fumoto T, Gaydon D, Marcaida M, Nakagawa H, Oriol P, Ruane AC, Ruget F, Singh B, Singh U, Tang L, Tao F, Wilkens P, Yoshida H, Zhang Z, Bouman B, 2015: Uncertainties in predicting rice yield by current crop models under a wide range of climatic conditions. Global Change Biology 21, 1328-1341. DOI: 10.1111/gcb.12758.

Lur HS, Wu YC, Chang SJ, Lao CL, Kondo M, 2009: Effects of high temperature on yield and grain quality of rice in Taiwan. Proceeding of the MARCO Symposium. (ed. by Hasegawa T, Sakai H). 5-9 October 2009, National Institute for Agro-Environmental Sciences, Tsukuba, Japan, pp.38-43.

Masutomi Y, Arakawa M, Minoda T, Yonekura T, Shimada T, 2015: Critical air temperature and sensitivity of the incidence of chalky rice kernels for the rice cultivar "Sai-no-kagayaki". Agricultural and Forest Meteorology 203, 11-16.

Meinshausen M, Smith SJ, Calvin K, Daniel JS, Kainuma MLT, Lamarque J, Matsumoto K, Montzka SA, Raper SCB, Riahi K, Thomson A, Velders GJM, van Vuuren DPP, 2011: The RCP greenhouse gas concentrations and their extensions from 1765 to 2300. Climatic Change 109(1), 213-241.

Ministry of Agriculture, Forestry and Fisheries (MAFF), 2006a: Toward overcoming high temperature injury of wet-rice. Report on Countermeasures against High Temperature Injury. (in Japanese; http://www.maff.go.jp/j/kanbo/kihyo03/ gityo/g_kiko_hendo/suito_kouon/pdf/report.pdf; accessed 31 October, 2016).

Ministry of Agriculture, Forestry and Fisheries (MAFF), 2006b: Crop statistics. Ministry of Agriculture, Forestry and Fisheries, Tokyo.

Ministry of Agriculture, Forestry and Fisheries (MAFF), Food Safety and Consumer Affairs Bureau, 2010: Handy Directory of Fertilizer 2009. Association of Agriculture and Forestry Statistics (in Japanese).

Morita S, Wada H, Matsue Y, 2016: Countermeasures for heat damage in rice grain quality under climate change. Plant Production Science 19(1), 1-11.

Moss RH, Edmonds JA, Hibbard KA, Manning MR, Rose SK, van Vuuren DP, Carter TR, Emori S, Kainuma M, Kram T, Meehl GA, Mitchell JFB, Nakicenovic N, Riahi K, Smith SJ, Stouffer RJ, Thomson AM, Weyant JP, Wilbanks TJ, 2010: The next generation of scenarios for climate change research and assessment. Nature 463, 747-756.

Nagahata H, Shima K, Nakagawa H, 2006: Modeling and prediction of the occurrence of chalky grains in rice. Japanese Journal of Crop Science 75, 18-19 (in Japanese).

Nakagawa H, Horie T, 1995: Modelling and prediction of developmental process in rice II. A model for simulating panicle development based on daily photoperiod and temperature. Japanese Journal of Crop Science 64(1), 33-42 (in Japanese with English abstract).

Nakagawa H, Nagahata H, Tsukaguchi N, 2008: Modeling and prediction of occurrence of chalky grains in rice 2. Japanese Journal of Crop Science 77, 148-149 (in Japanese).

Nakagawa H, Yamagishi J, Miyamoto N, Motoyama M, Yano M, Nemoto K, 2005: Flowering response of rice to photoperiod and temperature: a QTL analysis using a phenological model. Theoretical and Applied Genetics 110, 778-786.

Nakicenovic N, Swart R, 2000: Special report on emission scenario. Cambridge University Press, UK, pp.570.
Okada M, Iizumi T, Hayashi Y, Yokozawa M, 2011a: Projecting climate change impacts both on rice quality and yield in Japan. Journal of Agricultural Meteorology 67(4), 285-295.

Okada M, Iizumi T, Hayashi Y, Yokozawa M, 2011b: Modeling the multiple effects of temperature and radiation on rice quality. Environmental Research Letters 6, 034031.

Seino H, 1993: An estimation of distribution of meteorological elements using GIS and AMeDAS data. Journal of Agricultural Meteorology 48, 379-383 (in Japanese with English abstract).

Seino H, 1997: Global climate change and food production in Japan. Journal of Agricultural Meteorology 52(5), 367-376.

Sharpley AN, Williams JR, 1990: EPIC-Erosion/Productivity Impact Calculator: 1. Model documentation. Technical Bulletin No. 1768. U.S. Department of Agriculture, Washington, DC, pp. 235.

Sugiura T, Sumida H, Yokoyama S, Ono H, 2012: Overview of recent effects of global warming on agricultural production in Japan. JARQ 46(1), 7-13.

Taylor KE, Stouffer RJ, Meehl GA, 2012: An overview of CMIP5 and the experiment design. Bulletin of the American Meteorological Society 93, 485-498.

Usui Y, Sakai H, Tokida T, Nakamura H, Nakagawa H, Hasegawa T, 2016: Rice grain yield and quality responses to free-air $\mathrm{CO}_{2}$ enrichment combined with soil and water warming. Global Change Biology 22(3), 1256-1270. DOI: 10.1111/gcb.13128.

Wakamatsu K, Sasaki O, Uezono I, Tanaka A, 2007: Effects of high air temperature during the grain-filling period on the grain quality of rice in warm regions of Japan. Japanese Journal of Crop Science 76, 71-78 (in Japanese with English abstract).

Wakiyama Y, Ohara G, Maruyama A, 2010: Developing a model to predict the incidence of immature rice kernel by analyzing the incidence of immature kernel with white portion caused by meteorological and growth conditions during the grain-filling period. Journal of Agricultural Meteorology 66(4), 255-267 (in Japanese with English abstract).

Yin X, Kropff MJ, Horie T, Nakagawa H, Centeno HGS, Zhu D, Goudriaan J, 1997: A model for photothermal responses of flowering in rice I. Model description and parameterization. Field Crops Research 51(3), 189-200.

Yokozawa M, Iizumi T, Okada M, 2009: Large scale projection of climate change impacts on variability in rice yield in Japan. Global Environmental Research 14, 199-206 (in Japanese).

Yonemura S, Yajima M, Sakai H, Morokuma M, 1998: Estimate of rice yield of Japan under the conditions with elevated $\mathrm{CO}_{2}$ and increased temperature by using third mesh climate data. Journal of Agricultural Meteorology 54(3), 235-245 (in Japanese with English abstract).

Yoshida H, Takehisa K, Kojima T, Ohno H, Sasaki K, Nakagawa $\mathrm{H}, 2016$ : Modeling the effects of $\mathrm{N}$ application on growth, yield and plant properties associated with the occurrence of chalky grains of rice. Plant Production Science 19(1), 30-42.

Yoshida R, Fukui S, Shimada T, Hasegawa T, Ishigooka Y, Yakayabu I, Iwasaki T, 2015: Adaptation of rice to climate change through a cultivar-based simulation: a possible cultivar shift in eastern Japan. Climate Research 64, 275-290.

Yoshida S, 1981: Fundamentals of rice crop science. International Rice Research Institute, Los Baños, Laguna, Philippines, pp.269.

Zhang S, Tao F, 2013: Modeling the response of rice phenology to climate change and variability in different climatic zones: Comparisons of five models. European Journal of Agronomy 45, 165-176. 